\title{
15. OXYGEN AND CARBON ISOTOPE DATA FROM LEG 74 FORAMINIFERS1
}

\author{
N. J. Shackleton and M. A. Hall, The Godwin Laboratory, Free School Lane, Cambridge CB2 3RS, England \\ and \\ A. Boersma, Lamont-Doherty Geological Observatory, Palisades, New York ${ }^{2}$
}

\begin{abstract}
Oxygen and carbon isotope measurements have been made in picked planktonic and benthonic foraminifers from the five sites drilled on Leg 74, covering the whole Cenozoic. For the Neogene, the coverage gives good information on the development of the vertical temperature structure of Atlantic deep water. For the Paleogene, vertical gradients were weak and it is possible to combine data from different sites to obtain a very detailed record of both the temperature and carbon isotope history of Atlantic deep waters.
\end{abstract}

\section{INTRODUCTION}

One of the purposes of the Leg 74 drilling was to provide a suite of sites in which deep-water ${ }^{18} \mathrm{O}$ paleotemperature measurements could be made over a range of paleodepths. Ultimately this will enable a better description of variations in the vertical temperature structure of the ocean through time. It is not possible to complete such an analysis in the time available for the preparation of the Initial Reports, but a start has been made in obtaining the data. This chapter summarizes results that have been obtained to date and will give a good indication of the potential of different parts of the section for isotopic work.

\section{METHODS AND RESULTS}

Oxygen and carbon isotope measurements were made using a VG Isogas 903 triple collector mass spectrometer to analyze carbon dioxide released from picked foraminifers. The standard method of reaction on line at $50^{\circ} \mathrm{C}$ using $100 \%$ orthophosphoric acid was employed; the reaction line in use is shown in Figure 1.

To obtain seafloor records, benthic foraminifers were selected for analysis. Where possible, monospecific or monogeneric assemblages were picked. Where this proved impractical, species which have similar deviations from isotopic equilibrium were grouped together. In a number of levels it was possible to analyze more than one picking and so provide further data on species-dependent departures from isotopic equilibrium. Appendix A shows the adjustment factors which have been applied to the species analyzed in this chapter in order to obtain as good an approximation as possible to seafloor equilibrium values for ${ }^{13} \mathrm{C}$ and ${ }^{18} \mathrm{O}$ values. These adjustments must be made to take account of genetically controlled departures from isotopic equilibrium (Duplessy et al., 1970; Shackleton, 1974; Vincent et al., 1979; Graham et al., 1981). Appendix B gives the raw values and Appendix C the values adjusted on the basis of Appendix A, averaged where more than one measurement was obtained, and with the age estimate used for plotting (based on the timescales developed in Shackleton et al., this volume). Appendix A includes a number of mixtures; we recognize that there is additional uncertainty involved in these cases since the relative contributions are not known, but we consider that measurements based on specified mixtures are at least better than analyses of unspecified mixed species. A small number of measurements in Appendix B that were neither used in Appendix C nor plotted in the

\footnotetext{
${ }^{1}$ Moore, T. C., Jr., Rabinowitz, P. D., et al., Init. Repts. DSDP, 74: Washington (U.S. Govt, Printing Office).

2 Present address: P.O. Box 404, RR 1, Stony Point, New York.
}

figures are marked with asterisks. These values include bad analyses, out-of-place samples, and some values for which correction factors are unknown or unreliable. For example, Oridorsalis appears to be close to isotopic equilibrium for ${ }^{18} \mathrm{O}$, but to be erratic in its ${ }^{13} \mathrm{C}$ composition. It is possible that this reflects the presence of more than one species, or a significant effect of size on isotopic composition. It is interesting to note that Savin et al. (1981) found a perplexing variation in the difference in ${ }^{13} \mathrm{C}$ content between Oridorsalis and other species.

Figure 2 shows the oxygen and carbon isotope records for benthic and planktonic foraminifers from Sites 525-529. Oxygen isotope values are adjusted for departures from isotopic equilibrium (Shackleton, 1974), and carbon isotope values are adjusted so as to provide an estimate of the ${ }^{13} \mathrm{C}$ content of ocean deep water; members of the Cibicides genus are thought to provide a good estimate of this quantity in the modern ocean (Graham et al., 1981; Duplessy et al., pers. comm. 1982; Vincent et al., 1981) so that adjustments are made to Cibicides for ${ }^{13} \mathrm{C}$ and to Uvigerina for ${ }^{18} \mathrm{O}$. Because Site 526 is significantly shallower and at present the seafloor is bathed by a different water mass, values from this site cannot be plotted with those from the deeper sites.

For planktonic species, we still do not know the order of depth stratification sufficiently well to confidently pick the best surface indicator in every sample. Additionally, it is sometimes useful to obtain a record from deep-dwelling species as well as from surface species (Boersma and Shackleton, 1978; Biolzi, pers. comm., 1982). Thus Table 4 contains data from several different species in some samples.

In the discussion below, oxygen isotope values are discussed in terms of temperature $\left({ }^{\circ} \mathrm{C}\right)$ using the relationship between oxygen isotopic fractionation and temperature established by O'Neil et al. (1969) and discussed by Shackleton (1974). It is assumed that in the absence of an Antarctic ice sheet, the ocean had an oxygen isotopic composition of $-1.2 \%$ on the PDB scale (Shackleton and Kennett, 1975).

\section{DISCUSSION}

\section{Maestrichtian}

Analyses of a number of samples in the uppermost part of the Maestrichtian show that there is a significant deep-water temperature variability, with deep-water temperatures varying between about $10^{\circ}$ and $6.5^{\circ} \mathrm{C} \mathrm{(Fig.} \mathrm{2).}$ No values as cold as this were encountered again through the Paleocene or lower Eocene. No significant deep-water temperature difference was observed in the immediate vicinity of the Cretaceous/Tertiary boundary, at which time the deep-water temperature was about $10^{\circ} \mathrm{C}$.

Abathomphalus mayeroensis and Planoglobulina glabrata were analyzed in several Maestrichtian samples. Both ${ }^{13} \mathrm{C}$ and ${ }^{18} \mathrm{O}$ data indicate that of these two, the lat- 


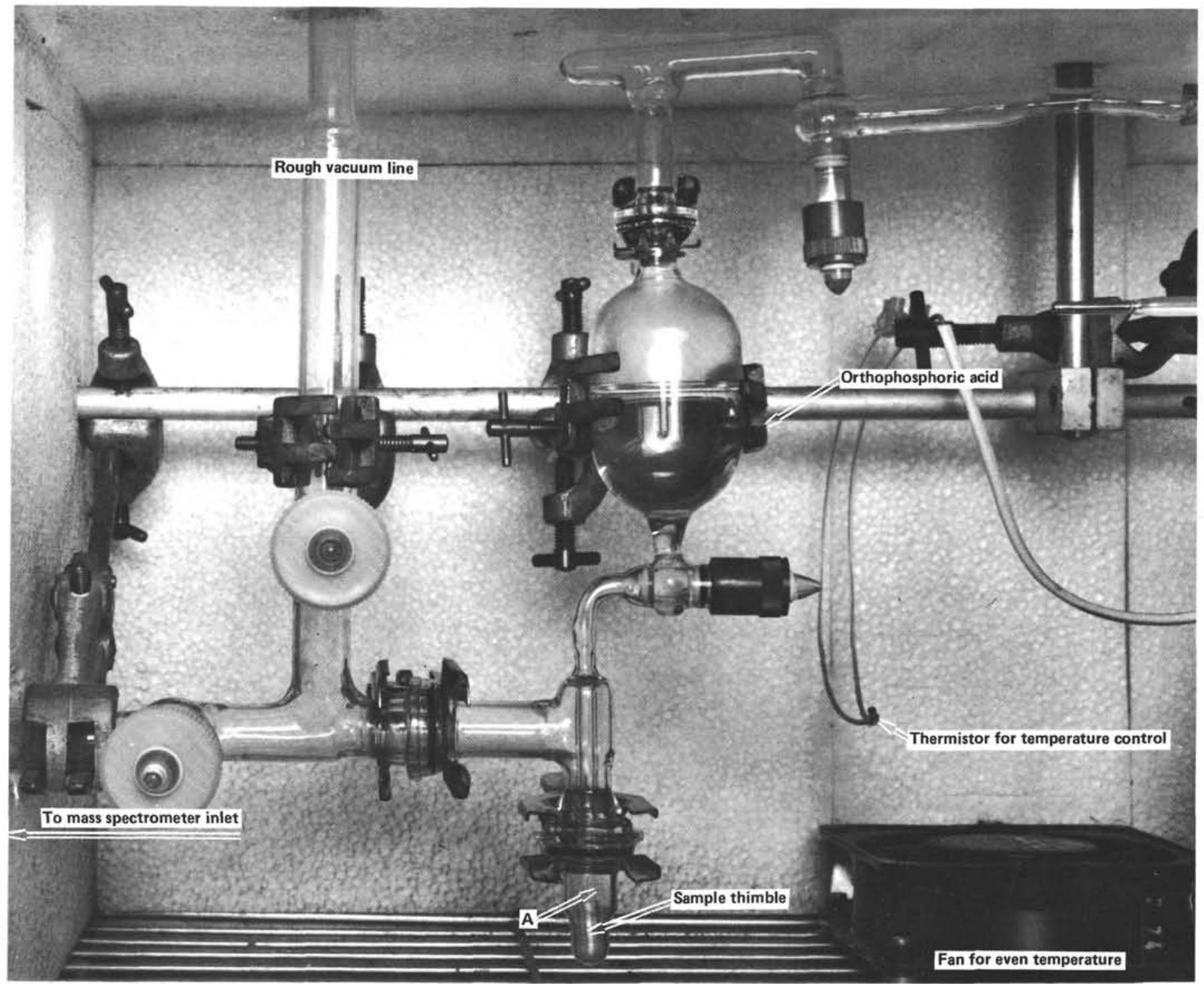

Figure 1. Reaction system used to generate $\mathrm{CO}_{2}$ from foraminifers for isotopic analysis. The whole region illustrated is kept at $50^{\circ} \mathrm{C}$. Orthophosphoric acid is dropped onto the foraminifers, which have previously been cleaned and vacuum-roasted in the thimble visible within container $\mathrm{A}$. The acid is replenished monthly and is kept pumped so that it does not take up moisture.

ter calcified closer to the sea surface; on the basis of its isotopic composition surface temperatures between $13^{\circ}$ and $16^{\circ} \mathrm{C}$ may be calculated. Mixed, very small $(63-75$ $\mu \mathrm{m})$ species from a sample in Hole 527 at $280.10 \mathrm{~m}$ (10 $\mathrm{cm}$ below top of Maestrichtian) yield ${ }^{18} \mathrm{O}$ and ${ }^{13} \mathrm{C}$ values closer to those given by $A$. mayeroensis, implying that they are not good indicators of surface conditions.

\section{Paleocene-Eocene}

No remarkable changes in deep-water temperature occurred during the Paleocene, although there was apparently less variability and a somewhat higher mean temperature than during the late Maestrichtian. In the early Eocene a significant rise in deep-water temperature is observed, culminating in temperatures of about $12^{\circ} \mathrm{C}$. After a few million years a considerable decline in temperature occurred relatively rapidly at about $50 \mathrm{Ma}$. The dating of this event is well controlled to within the interval of Magnetic Anomaly 21 on the basis of the measure- ments in Core 527-17. Only a small amount of late Eocene data was obtained; however, the values are consistent with those observed elsewhere, implying a deep-water temperature of about $7^{\circ} \mathrm{C}$. The temperature decline within Magnetic Anomaly 21 was not unidirectional but was accompanied by considerable variability that would warrant detailed investigation in a site with a higher accumulation rate over this interval.

Surface temperature appears to have been low in the first $2 \mathrm{~m}$.y. of the Paleocene, but this is probably an artifact of our inability to analyze species which truly reflect surface conditions. Mixed, very small (63-75 $\mu \mathrm{m})$ planktonic foraminifers dominated by Woodringina and carefully cleaned of obvious Cretaceous specimens were analyzed from $279.91 \mathrm{~m}$ in Hole 527 and yielded an ${ }^{18} \mathrm{O}$ value similar to that of the sample analyzed at the top of the Maestrichtian. Because, as already mentioned, this Maestrichtian measurement was not regarded as a good estimate of surface temperature, we have no reason to 
suppose that the Danian measurement enables us to estimate lowermost Danian surface temperature. On the other hand, these very small foraminifers do register essentially the same change in ${ }^{13} \mathrm{C}$ values that is registered by bulk sediment (Shackleton and Hall, this volume). Thus it seems likely that these specimens were calcifying relatively close to the sea surface (certainly well above the oxygen minimum). If the oxygen isotopic composition of these very small specimens is not significantly affected by post-depositional processes (which cannot be definitely established), then we may reasonably argue that the similarity in ${ }^{18} \mathrm{O}$ values between the very small specimens analyzed on either side of the Cretaceous/Tertiary boundary constitutes evidence that there was not a significant change in surface temperature at that boundary. However, this is a difficult point to establish conclusively.

Later in the Paleocene and in the early Eocene, surface temperatures were apparently higher than during the Maestrichtian or, indeed, than during any other part of the Cenozoic. Surface temperatures dropped during the middle Eocene just as deep-water temperatures did. It is interesting to note that this more or less parallel trend in surface and deep-water temperatures during the Eocene shows that there was no thermal isolation between mid-latitude and high-latitude water masses.

Preliminary examination of the benthic data suggests that the vertical temperature and ${ }^{13} \mathrm{C}$ gradients between Sites 525 and 527 were too small during the Paleocene to be measured without considerably more data. The two sites then occupied approximately the same positions in the water column as Sites 526 and $\mathbf{5 2 5}$ occupy today; thus there would have been measurable isotopic differences between them, given oceanographic gradients similar to those now prevailing.

\section{Oligocene}

At Site 529 detailed measurements were made at the Eocene/Oligocene boundary, where a very sharp transition was observed. The data should be regarded with caution, however, since the nannofossil $I$. recurvus is not present in the uppermost Eocene sediments, implying that the latest Eocene may be missing at this site (Manivit, this volume). It is interesting to note that the oxygen isotope values obtained in benthic foraminifers just above the boundary (or hiatus) are the most positive observed in the Oligocene. The values, about $+2.5 \%$ (adjusted to isotopic equilibrium), are in fact similar to the lightest values observed in the late Miocene. This value may be regarded as favoring the presence of an ice sheet in Antarctica for a brief interval in the early Oligocene; in the absence of any significant quantity of ice, a value of $+2.5 \%$ o would indicate a temperature of $2{ }^{\circ} \mathrm{C}$ at a paleodepth of around $3000 \mathrm{~m}$. This would certainly imply at least freezing winters at sea level around Antarctica, which itself would be consistent with substantial glaciation. It seems perhaps more likely that deep water was not so cold as $2^{\circ}$, and that there was a significant amount of ice on Antarctica for this short interval early in the Oligocene. (An isolated measurement from $225.67 \mathrm{~m}$ at Site 528 gave an even more positive ${ }^{18} \mathrm{O}$ value, but this may have been the result of mixing with one or more Neogene specimens, since the sample proved to contain some drillpipe rust indicative of downhole contamination).

Although we conclude that there may have been some accumulation of ice on Antarctica during the early Oligocene, as claimed by Matthews and Poore (1980), we have reached this conclusion by accumulating more benthic foraminiferal data and extending the argument used by Shackleton and Kennett (1975). We do not agree with the approach taken by Matthews and Poore (1980), who have argued that global ice volume in the Cenozoic may be estimated by assuming that the surface temperature in the tropics is more or less invariant. Indeed, were one to apply this argument to the data set discussed by Shackleton and Boersma (1981), one would conclude that during the early Eocene ocean surface temperature ranged between $28^{\circ} \mathrm{C}$ at the equator and $18^{\circ} \mathrm{C}$ at high latitudes, while somewhere on the continents sufficient ice was stored to render the oceans even more isotopically positive than today. For the early Oligocene, Poore and Matthews (in press) have obtained a data set considerably more detailed than ours; it documents isotopically positive values similar to those that we have obtained, but their interpretation is again based on the model of Matthews and Poore (1980), with which we disagree.

The total range in ${ }^{18} \mathrm{O}$ values in benthic samples from the Oligocene at Sites 528 and 529 is of the order $0.7 \%$ (from 1.8 to $2.5 \%$ ), but this is among a relatively small number of analyses and must underestimate the total range of variation.

Site 526, where the paleodepth was significantly shallower during the Oligocene than the present $1000 \mathrm{~m}$, shows a rather different benthic temperature record. The values are isotopically lighter by the equivalent of $2-3^{\circ}$, and show a greater variability of about $1 \%$, or more than $3^{\circ}$. Unfortunately, the isotopic results from Site 526 sediments are somewhat unsatisfactory. Differences between species are not as one expects on the basis of present-day calibrations or of between-species comparisons at other sites. Matthews et al. (1980) have suggested that, in very shallow sites, aragonite that was preserved during initial sedimentation may very readily go into solution in the pore waters and reprecipitate on the foraminifers. If this is indeed the case, the values obtained may actually be closer to deep-water isotopic equilibrium than the original calcite was; this would explain the fact that between-species differences are very small in these sediments.

\section{Early-Middle Miocene}

Unfortunately the middle Miocene was not well recovered at any Leg 74 site. However, the fragmentary recovery is sufficient to reveal the deep-water temperature maximum of the middle Miocene and the associated positive extreme in ${ }^{13} \mathrm{C}$ values first observed by Shackleton and Kennett (1975) and to give hints of the important high-frequency variation in both isotope ratios that was revealed for the first time by the detailed work of Woodruff et al. (1981) from DSDP Site 289. Comparison of the planktonic and benthic records (Fig. 2A) 


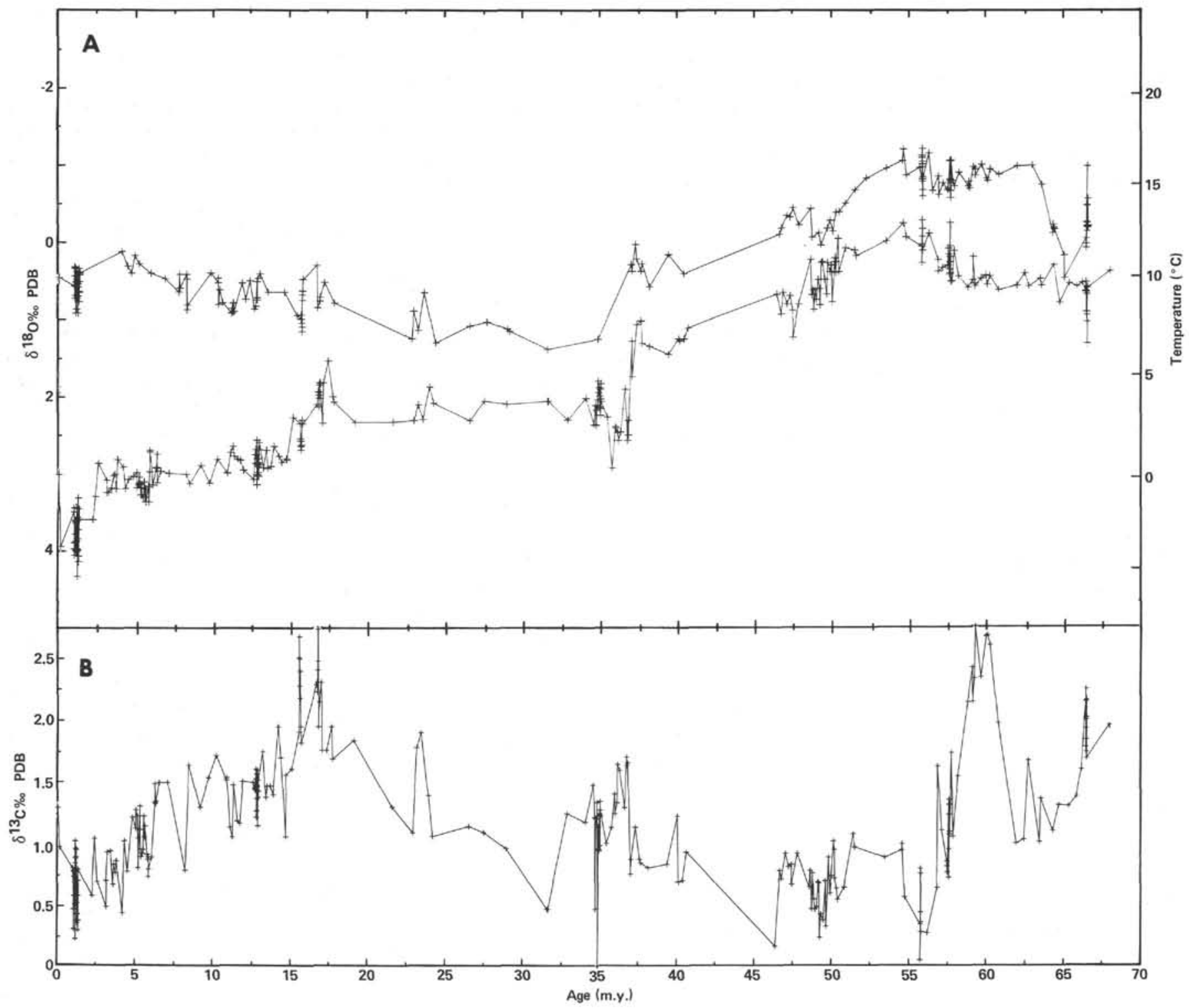

Figure 2. A. Oxygen isotope record in benthic and planktonic foraminifers from Sites 525-529, Maestrichtian to Recent. For planktonic species, data are selected to represent as well as possible those species that apparently calcify near the ocean surface. The temperature scale is calculated for a time without an Antarctic ice sheet. B. Carbon isotope record in benthic foraminifers from Sites 525-529, Maestrichtian to Recent. All data in Figure 2A-B are plotted on a common timescale (from Appendix C). C. Carbon isotope record in planktonic foraminifers from Sites 525-529, Maestrichtian to Recent. All data are plotted on a common timescale (from Appendix D). In samples from which more than one species was analyzed, the isotopically heaviest value is plotted, and analyses of species which are known to deposit their carbonate at depth are not plotted.

shows that the temperature gradient between surface and deep water was approximately the same from the late Eocene to the middle Miocene.

\section{Late Miocene and Pliocene: Changing Vertical Gradients}

The drilling of Site 526 provided the unusual opportunity of examining the vertical temperature and ${ }^{13} \mathrm{C}$ gradients within the ocean interior and the evolution of these gradients through the late Miocene. Table 1 shows mean ${ }^{18} \mathrm{O}$ and ${ }^{13} \mathrm{C}$ values over $1 \mathrm{~m}$.y. increments (from Appendix C) in Sites 526 and 525.

It is striking that the vertical temperature gradient between the two sites was approximately $1^{\circ}$ throughout this interval, with only rather subtle variations, whereas the carbon isotopic gradient actually reversed in the lower Pliocene. Today, Site 526 is bathed by Antarctic Intermediate Water (AIW) with a lower ${ }^{13} \mathrm{C}$ content than the North Atlantic Deep Water (NADW) that is found at the depth of the seafloor at Site $525(\sim 2500$ $\mathrm{m}$ ); the ${ }^{13} \mathrm{C}$ difference is about $0.2 \%$ (Kroopnick, 1981 , from Station 103). In parts of the lower Pliocene, benthic foraminifers from Site 526 were isotopically more positive than at Site 525 . Table 2 shows values from the deep Pacific; during the early Pliocene there was clearly an isotopic gradient between the South Atlantic and the deep Pacific just as strong as there is today, and it seems likely that NADW extended up to the depth of Site 526, perhaps with a reduction in the formation of AIW. These data show that the conclusion reached by Keigwin 


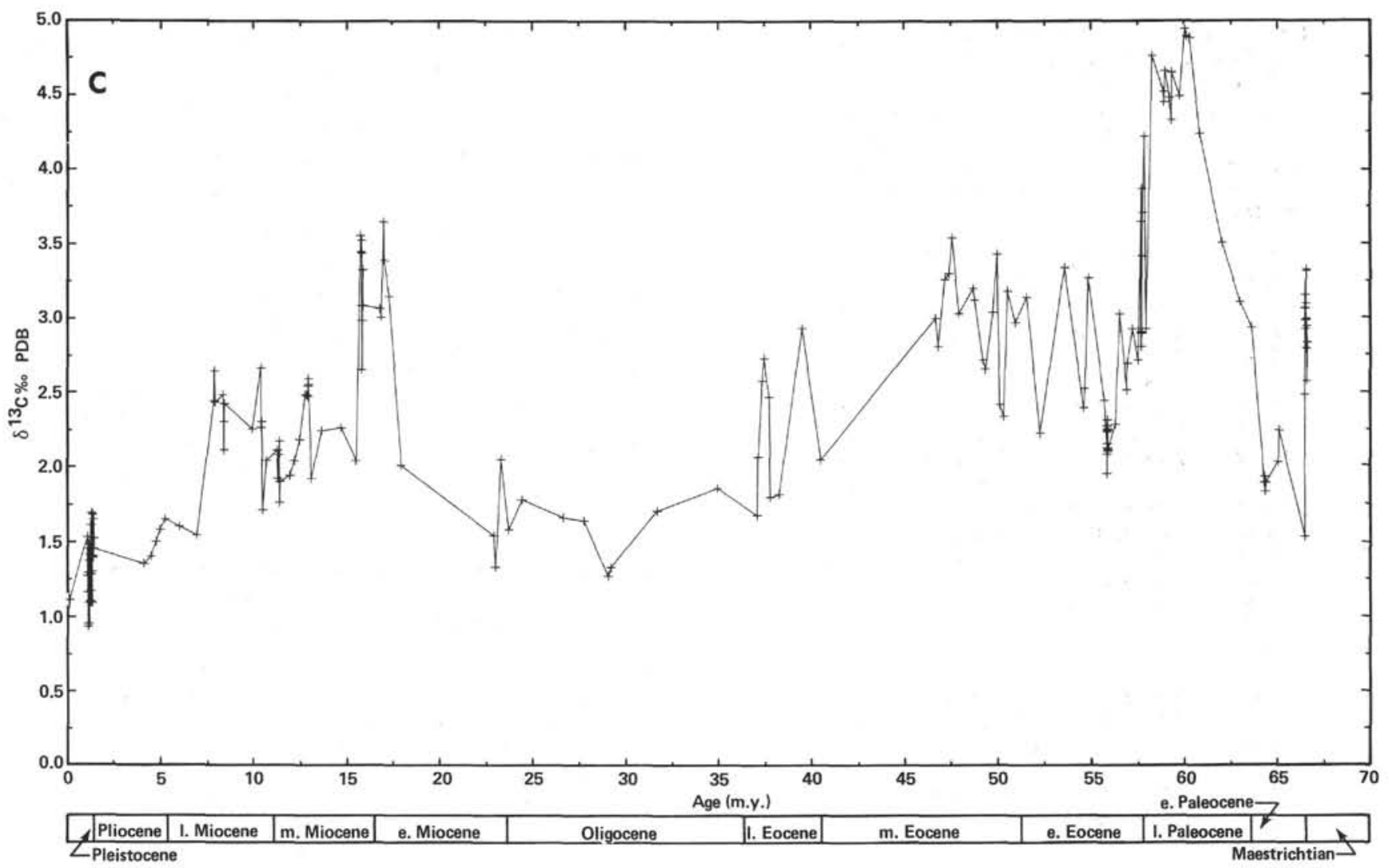

Figure 2. (Continued).

(1982), that the production of NADW was significantly less before the Panama Isthmus closed about $3 \mathrm{Ma}$, is not correct. Our data show an early Pliocene ${ }^{13} \mathrm{C}$ difference between South Atlantic NADW and deep Pacific water of more than $1 \%$ well prior to that event. It may be that the early Pliocene Caribbean is not an appropriate position from which to monitor the ${ }^{13} \mathrm{C}$ content of NADW.

The so-called "carbon shift" at about $6.4 \mathrm{Ma}$ (Haq et al., 1980), when ocean-dissolved $\mathrm{CO}_{2}$ became isotopically lighter for ${ }^{13} \mathrm{C}$, is reasonably clearly expressed and indeed has been used as a guide to correlating Holes 525B and 526. Occurring just above the appearance of Amaurolithus primus at Hole 525B, it provides a useful datum, because this first appearance was not readily determined under the conditions of more extensive overgrowth observed in the late Miocene nannofossils of Site 526. However, it is certainly not such a striking effect as is observed in the Pacific, and indeed there is a clear overlap between pre-"carbon shift" values and those observed in the lower Pliocene (Fig. 2B).

The deep-water ${ }^{18} \mathrm{O}$ record of the late Miocene is thought to reflect the history of Antarctic glaciation, and the isotopic difference between the mean value for 16-17 Ma and today's equilibrium value is about $1.2 \%$. This means that if ocean isotopic composition changed by about $0.9 \%$ (Shackleton and Kennett, 1975), there was a deep-water temperature drop of only a little over a degree. By contrast, surface temperatures changed considerably; the temperature difference between the surface and the deep water bathing the shallowest site (526) has increased by about $6^{\circ} \mathrm{C}$ since the middle Miocene. This dramatic increase in temperature gradients during the last $15 \mathrm{Ma}$ is a fascinating aspect of global paleoclimatology. It must be emphasized again that its interpretation is not affected by current uncertainty (Matthews and Poore, 1980) regarding the history of global oceanic isotopic composition, which affects the absolute temperatures estimated, but not temperature gradients.

\section{Pleistocene}

A lower Pleistocene section was analyzed from Hole 528A, where Cores 4-6 were sampled at close intervals. Benthic foraminifers were analyzed in part of the section, chiefly as a check on the reliability of the data obtained. Evidently early Pleistocene climatic variability is easily detectable. With only a single penetration of the site it would not be possible to obtain a long record suitable for spectral analysis. However, the material is suitable for paleoclimatic work; both faunal change and dissolution variability could be examined in relation to the ${ }^{18} \mathrm{O}$ record in this material.

\section{CONCLUSIONS}

The ${ }^{18} \mathrm{O}$ analyses in benthic foraminifers record the largely well-established temperature and ice-volume history of the Cenozoic. The temperature maximum in the early Eocene, the cooling early in the middle Eocene, and the very rapid cooling at the Eocene/Oligocene boundary are all well displayed. The accumulation of 
Table 1. Oxygen and carbon isotope data averaged in million-year increments for Sites 525 and 526, Pliocene to middle Miocene.

\begin{tabular}{lccc}
\hline Increment & $\begin{array}{c}\delta^{18} \mathrm{O} \\
(\%)\end{array}$ & $\begin{array}{c}\delta^{13} \mathrm{C} \\
(\%)\end{array}$ & $\begin{array}{c}\text { No. of } \\
\text { analyses }\end{array}$ \\
\hline
\end{tabular}

\begin{tabular}{cllr}
\hline Site 525 & & & \\
& & & \\
$3-4$ & $3.17 \pm 0.10$ & $0.79 \pm 0.17$ & 6 \\
$4-5$ & $3.06 \pm 0.12$ & $0.87 \pm 0.33$ & 4 \\
$5-6$ & $3.14 \pm 0.19$ & $1.02 \pm 0.17$ & 19 \\
$6-7$ & $2.97 \pm 0.15$ & $1.32 \pm 0.22$ & 6 \\
$7-8$ & 3.00 & 1.50 & 1 \\
$8-9$ & 3.13 & 1.64 & 1 \\
$9-10$ & $3.01 \pm 0.16$ & $1.42 \pm 0.17$ & 2 \\
$10-11$ & $2.93 \pm 0.11$ & $1.59 \pm 0.11$ & 3 \\
$11-12$ & $2.79 \pm 0.10$ & $1.29 \pm 0.19$ & 6 \\
$12-13$ & $2.85 \pm 0.15$ & $1.44 \pm 0.12$ & 20 \\
$13-14$ & $2.82 \pm 0.14$ & $1.49 \pm 0.15$ & 5 \\
$14-15$ & $2.81 \pm 0.03$ & $1.57 \pm 0.37$ & 4 \\
$15-16$ & $2.49 \pm 0.16$ & $2.18 \pm 0.35$ & 10 \\
$16-17$ & $1.96 \pm 0.12$ & $2.32 \pm 0.23$ & 8 \\
$17-24$ & $2.09 \pm 0.25$ & $1.65 \pm 0.37$ & 12
\end{tabular}

Site 526

\begin{tabular}{cllr}
$3-4$ & $2.78 \pm 0.12$ & $1.11 \pm 0.27$ & 11 \\
$4-5$ & $2.96 \pm 0.10$ & $0.94 \pm 0.18$ & 26 \\
$5-6$ & $2.91 \pm 0.12$ & $0.91 \pm 0.16$ & 25 \\
$6-7$ & $2.76 \pm 0.10$ & $1.07 \pm 0.23$ & 24 \\
$7-8$ & $2.79 \pm 0.09$ & $1.47 \pm 0.22$ & 11 \\
$8-9$ & $2.89 \pm 0.07$ & $1.51 \pm 0.09$ & 6 \\
$9-10$ & $2.87 \pm 0.16$ & $1.44 \pm 0.14$ & 10 \\
$10-11$ & $2.92 \pm 0.11$ & $1.42 \pm 0.10$ & 11 \\
$11-12$ & $2.67 \pm 0.14$ & $1.22 \pm 0.17$ & 8 \\
$12-13$ & $2.63 \pm 0.17$ & $1.36 \pm 0.15$ & 14 \\
$13-14$ & $2.51 \pm 0.14$ & $1.54 \pm 0.14$ & 19 \\
$14-15$ & $2.33 \pm 0.09$ & $1.64 \pm 0.36$ & 2 \\
$16-16$ & No data & & \\
$16-17$ & $2.05 \pm 0.23$ & $2.24 \pm 0.36$ & 4 \\
$17-24$ & $1.73 \pm 0.20$ & $1.59 \pm 0.22$ & 7 \\
\hline
\end{tabular}

Table 2. Oxygen and carbon isotope data averaged in million-year increments for deep equatorial Pacific cores V28-179, V28-185, and RC12-66.

\begin{tabular}{cccc}
\hline Increment & $\begin{array}{c}\delta^{18} \mathrm{O} \\
(\%)\end{array}$ & $\begin{array}{c}\delta^{13} \mathrm{C} \\
(\%)\end{array}$ & $\begin{array}{c}\text { No. of } \\
\text { analyses }\end{array}$ \\
\hline $3-4$ & $3.31 \pm 0.23$ & $-0.22 \pm 0.23$ & 49 \\
$4-5$ & $3.06 \pm 0.17$ & $-0.30 \pm 0.25$ & 39 \\
$5-6$ & $3.22 \pm 0.13$ & $-0.22 \pm 0.20$ & 26 \\
$6-7$ & $3.09 \pm 0.17$ & $-0.10 \pm 0.29$ & 23 \\
\hline
\end{tabular}

Note: Sources are: Shackleton and Opdyke, 1977; Keigwin and Shackleton, 1980; Shackleton, 1982; and Shackleton, unpublished data). Note that the data in the increment 6-7 m.y. are virtually all from between 6 and $6.5 \mathrm{Ma}$, after the late Miocene ${ }^{13} \mathrm{C}$ change.

Antarctic ice in the middle Miocene is clearly recorded although sediment recovery was poor in this part of the section and details of the transition are not well resolved. A good late Miocene record at Site $\mathbf{5 2 5}$ will clarify events during that time. A fairly good early Oligocene record is also available from Site 529. Although frequent slumps would preclude use of this section for detailed time-series analysis, it provides important evidence supporting the existence of limited Antarctic glaciation during the earliest Oligocene. The details of the Paleogene section permit the climatic events to be better dated than before. High deep-water temperatures were attained close to the Paleocene/Eocene boundary at about $56 \mathrm{Ma}$, and a temperature decline occurred over a period of about a million years early in the middle Eocene ( $\sim 50-49 \mathrm{Ma})$.

\section{ACKNOWLEDGMENTS}

We are deeply grateful to Captain Clark and the team aboard the Glomar Challenger for Leg 74 for successfully drilling our objectives and enabling these studies to be carried out. Laboratory work was supported by NERC Grant GR3/3606 to N.J.S. We thank C. Solanki and M. Tabecki for laboratory assistance and John Line for computing advice. We are very grateful to R. K. Matthews, E. Vincent, and T. C. Moore for their helpful reviews of the manuscript, and especially to the former for making available the manuscript of his joint contribu-tion with R. Z. Poore to Volume 73 of the Initial Reports (Poore and Matthews, in press).

\section{REFERENCES}

Belanger, P. E., Curry, W. B., and Matthews, R. K., 1981. Core-top evaluation of benthic foraminiferal isotopic ratios for paleo-oceanographic interpretations. Palaeogeogr., Palaeoclimatol., Palaeoecol., 33:205-220.

Boersma, A., and Schackleton, N. J., 1978. Oxygen and carbon isotope record through the Oligocene, DSDP Site 366, Equatorial Atlantic. In Lancelot, Y., Seibold, E., et al., Init. Repts. DSDP, 41: Washington (U.S. Govt. Printing Office), 957-962.

Duplessy, J.-C., Lalou, C., and Vinot, A. C., 1970. Differential isotopic fractionation in benthic foraminifera and palaeotemperatures reassessed. Science, 168:250-251.

Graham, D. W., Corliss, B. H., Bender, M. L., and Keigwin, L. D., Jr., 1981. Carbon and oxygen isotopic disequilibria of recent deepsea benthic Foraminifera. Mar. Micropaleontol., 6:483-497.

Haq, B. U., et al., 1980. Late Miocene carbon isotopic shift and synchroneity of some phytoplanktonic biostratigraphic events. Geology, 8:427-431.

Keigwin, L. D., Jr., 1979. Late Cenozoic stable isotope stratigraphy and paleoceanography of DSDP sites from the east equatorial and central north Pacific Ocean. Earth Planet. Sci. Lett., 45:361-382. 1982. Isotopic paleoceanography of the Caribbean and East Pacific: Role of Panama Uplift. Science, 217:350-353.

Keigwin, L. D., Jr., and Shackleton, N. J., 1980. Uppermost Miocene carbon isotope stratigraphy of a piston core in the equatorial $\mathrm{Pa}-$ cific. Nature, 284:613-614.

Kroopnick, P., 1980. The distribution of ${ }^{13} \mathrm{C}$ in the Atlantic Ocean. Earth Planet. Sci. Lett., 49:469-484.

Matthews, R. K., Curry, W. B., Lohman, K. E., Sommer, M. A., and Poore, R. Z., 1980. Late Miocene palaeo-oceanography of the Atlantic: Oxygen isotope data on planktonic and benthic Foraminifera. Nature, 283:555-557.

Matthews, R. K., and Poore, R. Z., 1980. Tertiary $\delta^{18} \mathrm{O}$ record and glacio-eustatic sealevel fluctuations. Geology, 8:501-504.

O'Neil, J. R., Clayton, R. N., and Mayeda, T. K., 1969. Oxygen isotope fractionation in divalent metal carbonates. J. Chem. Phys., 51:5547-5558.

Poore, R. Z., and Matthews, R. K., in press. Late Eocene-Oligocene oxygen and carbon isotope record from South Atlantic Ocean, Deep Sea Drilling Project Site 522. In Hsü, K. J., LaBrecque, J. L., et al., Init. Repts. DSDP, 73: Washington (U.S. Govt. Printing Office).

Savin, S. M., Douglas, R. G., Keller, G., Killingley, J. S., Shaughnessy, L., Sommer, M. A., Vincent, E., and Woodruff, F., 1981. Miocene benthic foraminiferal isotope records: A synthesis. Mar. Micropalaeontol., 6:423-450.

Shackleton, N. J., 1974. Attainment of isotopic equilibrium between ocean water and the benthonic Foraminifera genus Uvigerina: Isotopic changes in the ocean during the last glacial. C.N.R.S. Colloquium, 219:203-209.

1982. The deep sea sediment record of climatic variability. Prog. Oceanogr., 11:199-218.

Shackleton, N. J., and Boersma, A., 1981. The climate of the Eocene ocean. J. Geol. Soc. London, 138:153-157. 
Shackleton, N. J., Imbrie, J., and Hall, M. A., in press. Oxygen and carbon isotope record of East Pacific core V19-30: implications for the formation of deep water in the late Pleistocene North Atlantic. Earth Planet. Sci. Lett.

Shackleton, N. J., and Kennett, J. P., 1975. Paleotemperature history of the Cenozoic and the initiation of Antarctic glaciation: Oxygen and carbon isotope analyses in DSDP Sites 277,279 , and 281. In Kennett, J. P., Houtz, R. E., et al., Init. Repts. DSDP, 29: Washington (U.S. Govt. Printing Office), 743-755.
Shackleton, N. J., and Opdyke, N. D., 1977. Oxygen isotope and palaeomagnetic evidence for early Northern Hemisphere glaciation. Nature, 270:216-219.

Vincent, E., Killingley, J. S., and Berger, W. H., 1981. Stable isotopes in benthic Foraminifera from Ontong-Java Plateau, box cores ERDC 112 and 123. Palaeogeogr., Palaeoclimatol., Palaeoecol., 33:221-230.

Woodruff, F., Savin, S. M., and Douglas, R. G., 1981. Miocene stable isotope record: A detailed Pacific ocean study and its paleoclimatic implications. Science, 212:665-668.

\section{APPENDIX A}

Isotopic Analyses of Benthic and Planktonic Foraminifers

Adjustment factors applied to the isotopic analyses of benthic foraminiferal species in order to obtain the best estimates of oxygen isotopic equilibrium and carbon isotopic composition of ocean deep-water dissolved $\mathrm{CO}_{2}$.

\begin{tabular}{|c|c|c|c|}
\hline \multirow{2}{*}{$\begin{array}{l}\text { Genus } \\
\text { or Species }\end{array}$} & \multirow{2}{*}{$\begin{array}{l}\text { Computer } \\
\text { Abbreviation }\end{array}$} & \multicolumn{2}{|c|}{ Adjustment } \\
\hline & & ${ }^{18} \mathrm{O}$ & ${ }^{13} \mathrm{C}$ \\
\hline Uvigerina & UVIG & 0.0 & 0.9 \\
\hline Hoeglundina & HELEGANS & -0.40 & -1.3 \\
\hline Cibicidoides & CIB & 0.5 & 0.0 \\
\hline C. kullenbergi & CIBKULL & 0.5 & 0.0 \\
\hline C. wuellerstorffi & PWUELL & 0.64 & 0.0 \\
\hline C. havanensis & CIBHAV & 0.5 & 0.0 \\
\hline Melonis & MELONIS & 0.3 & 0.8 \\
\hline M. pompilliodes & MELPOMP & 0.3 & 0.6 \\
\hline M. barleearnum & MELBARL & 0.4 & 1.0 \\
\hline Bulimina & BULIMINA & 0.0 & 0.0 \\
\hline B. jarvisi & BJARV & 0.0 & 0.0 \\
\hline Globocassidulina & GLOBOCAS & -0.1 & 0.5 \\
\hline Nuttalides & NUTT & 0.35 & 0.0 \\
\hline Gavelinella & GAVELIN & 0.3 & 0.0 \\
\hline Gyroidina & GYROID & 0.0 & 0.0 \\
\hline Oridorsalis & ORID & 0.0 & 1.0 \\
\hline Stilostomella & STABYSS & -0.15 & 1.0 \\
\hline Sphaeroidina & SBULL & -0.1 & -0.1 \\
\hline Favocassidulina & FAVOCASS & -0.1 & 0.5 \\
\hline Planulina renzi & PRENZI & 0.6 & 0.0 \\
\hline Pullenia bulloides & PULBUL & 0.0 & 0.3 \\
\hline Rectuvigerina & RECTUVIG & 0.0 & 0.9 \\
\hline Anomalinoides & ANOMALIN & 0.3 & 0.3 \\
\hline Gavelinella & GAVELIN & 0.3 & 0.0 \\
\hline Nodosaria & NOD & 0.0 & 0.0 \\
\hline Osangularia & OSANG & 0.0 & 0.0 \\
\hline NUTT + CIB & NUTTCIB & 0.4 & 0.0 \\
\hline UVIG + GLOBOCAS & UVIGGLOB & -0.05 & 0.7 \\
\hline PWUELL + CIBKULL & WUELKULL & 0.5 & 0.0 \\
\hline GLOBOCAS + BJARV & GLOBOJAR & 0.0 & 0.25 \\
\hline ORID etc. & ORIDMIX & 0.0 & 0.5 \\
\hline ORID + BUL & ORIDBUL & 0.0 & 0.5 \\
\hline NUTT + ALAB & NUTTALAB & 0.4 & 0.0 \\
\hline $\mathrm{CIB}+\mathrm{GAV}$ & CIBGAV & 0.5 & 0.0 \\
\hline $\mathrm{BUL}+\mathrm{CIB}$ & BULCIB & 0.15 & 0.0 \\
\hline UVIG + STABYSS & UVIGSTIL & 0.0 & 1.0 \\
\hline GLOBOCAS + ORID & GLOBORID & 0.0 & 0.75 \\
\hline UVIG + GLOBOCAS & UVIGGLOB & 0.0 & 0.7 \\
\hline ORID + GYROID & ORIDGYR & 0.0 & 0.5 \\
\hline STABYSS + BJARV & STILJARV & 0.0 & 0.5 \\
\hline GLOBOCAS + STABYSS & GLOBSTIL & 0.0 & 0.7 \\
\hline UVIG + BUL & UVIGBUL & 0.0 & 0.45 \\
\hline NUTT + CIB & NUTTCIB & 0.4 & 0.0 \\
\hline NUTT + GAV & NUTTGAV & 0.35 & 0.0 \\
\hline
\end{tabular}

Note: These figures are derived from our assessment of all the data available to us. Although a slightly different set of adjustments might be derived on the basis of data from Leg 74 alone, we consider that this would impede comparison with other sites. 
APPENDIX B

Isotopic Analyses of Benthic Foraminifers from Sites 525-529

\begin{tabular}{|c|c|c|c|}
\hline $\begin{array}{l}\text { Sub-bottom } \\
\text { Depth } \\
\text { (m) }\end{array}$ & Species & $\begin{array}{l}\delta^{18} \mathrm{O} \\
(\% 6)\end{array}$ & $\begin{array}{c}\delta^{13} \mathrm{C} \\
(\%,)\end{array}$ \\
\hline Hole 525B & & & \\
\hline 0.80 & UVIG & 3.95 & 0.08 \\
\hline 11.66 & FAVOCASS & 3.69 & -0.03 \\
\hline 11.66 & PWUELL & 2.96 & 0.70 \\
\hline 13.05 & GLOBOCAS & 3.40 & 0.50 \\
\hline 13.05 & PWUELL & 2.66 & 1.10 \\
\hline 19.01 & PWUELL & 2.45 & 0.50 \\
\hline 19.34 & PWUELL. & 2.61 & 0.71 \\
\hline 22.10 & GLOBOCAS & 3.41 & 0.51 \\
\hline 22.20 & CIBKULL & 2.64 & 0.87 \\
\hline 22.20 & NUTT & 3.21 & 0.27 \\
\hline 22.20 & GLOBOCAS & 3.32 & 0.57 \\
\hline 22.20 & PWUELL & 2.76 & 0.86 \\
\hline 22.40 & CIBKULL & 2.89 & 0.74 \\
\hline 22.40 & GLOBOCAS & 3.73 & 0.49 \\
\hline 22.40 & PWUELL & 2.90 & 0.74 \\
\hline 23.61 & GLOBOCAS & 3.28 & 0.36 \\
\hline 27.78 & GLOBOCAS & 3.29 & 0.45 \\
\hline 33.35 & GLOBOCAS & 3.11 & 0.34 \\
\hline 35.10 & GLOBOCAS & 3.30 & 0.27 \\
\hline 42.26 & PWUELL & 2.28 & 0.45 \\
\hline 44.88 & GLOBOCAS & 3.30 & 0.53 \\
\hline 48.05 & GLOBOCAS & 3.18 & 0.28 \\
\hline 54.08 & GLOBOCAS & 3.14 & 0.72 \\
\hline 55.58 & GLOBOCAS & 3.14 & 0.96 \\
\hline 58.81 & GLOBOCAS & 3.09 & 0.63 \\
\hline 59.11 & GLOBOCAS & 3.29 & 0.78 \\
\hline 60.31 & GLOBOCAS & 3.37 & 0.83 \\
\hline 61.71 & CIB & 2.57 & 1.14 \\
\hline 61.71 & GLOBOCAS & 3.32 & 0.81 \\
\hline 62.01 & GLOBOCAS & 3.44 & 0.79 \\
\hline 62.91 & GLOBOCAS & 3.17 & 0.26 \\
\hline 62.91 & STABYSS & 3.17 & 0.08 \\
\hline 62.91 & UVIG & 3.09 & 0.41 \\
\hline 63.21 & GLOBOCAS & 3.23 & 0.31 \\
\hline 66.81 & GLOBOCAS & 3.58 & 0.81 \\
\hline 66.81 & ORID & 3.07 & $-0.30^{*}$ \\
\hline 66.81 & UVIG & 3.31 & 0.42 \\
\hline 66.91 & GLOBOCAS & 3.24 & 0.62 \\
\hline 67.41 & GLOBOCAS & 3.29 & 0.46 \\
\hline 67.91 & $\mathrm{CIB}$ & 2.70 & 0.86 \\
\hline 67.91 & GLOBOCAS & 3.45 & 0.43 \\
\hline 70.61 & CIBKULL & 2.88 & 0.70 \\
\hline 70.61 & GLOBOCAS & 3.38 & 0.76 \\
\hline 70.61 & PRENZI & 2.67 & 0.82 \\
\hline 70.68 & PWUELL & 2.70 & 0.83 \\
\hline 72.11 & GLOBOCAS & 3.04 & 0.56 \\
\hline 72.11 & PRENZI & 2.67 & 0.85 \\
\hline 72.18 & PWUELL & 2.51 & 0.95 \\
\hline 73.61 & PWUELL & 2.67 & 1.23 \\
\hline 75.14 & GLOBOCAS & 3.30 & 0.56 \\
\hline 75.81 & OLOBOCAS & 3.64 & 0.78 \\
\hline 75.81 & PRENZI & 2.60 & 1.02 \\
\hline 79.06 & GLOBOCAS & 3.29 & 0.64 \\
\hline 79.06 & PWUELL & 2.51 & 0.73 \\
\hline 79.71 & CIBKULL & 2.79 & 0.76 \\
\hline 79.71 & GLOBOCAS & 3.24 & 0.56 \\
\hline 79.71 & PRENZI & 2.49 & 0.95 \\
\hline 81.01 & PRENZI & 2.77 & 0.88 \\
\hline 82.06 & GLOBOCAS & 3.08 & 0.40 \\
\hline 82.31 & GLOBOCAS & 2.88 & 0.30 \\
\hline 82.31 & PRENZI & 2.05 & 0.68 \\
\hline 82.49 & GLOBOCAS & 2.84 & 0.00 \\
\hline 82.49 & PWUELL & 2.20 & 0.79 \\
\hline 82.49 & UVIG & 2.52 & 0.22 \\
\hline 82.93 & GLOBOCAS & 3.11 & 0.47 \\
\hline 82.93 & PWUELL & 2.49 & 0.98 \\
\hline 88.01 & PRENZI & 2.55 & 0.90 \\
\hline 94.31 & GLOBOCAS & 3.01 & 0.90 \\
\hline 94.31 & PRENZI & 2.35 & 1.27 \\
\hline 95.04 & GLOBOCAS & 2.97 & 1.00 \\
\hline 95.04 & PRENZI & 2.37 & 1.48 \\
\hline 95.69 & GLOBOCAS & 2.85 & 0.83 \\
\hline 96.21 & GLOBOCAS & 3.22 & 0.85 \\
\hline $\begin{array}{l}97.71 \\
99.37\end{array}$ & GLOBOCAS & $\begin{array}{l}3.07 \\
2.64\end{array}$ & $\begin{array}{l}1.00 \\
1.40\end{array}$ \\
\hline $\begin{array}{l}99.37 \\
99.37\end{array}$ & $\begin{array}{l}\text { CIBKULL } \\
\text { GLOBOCAS }\end{array}$ & $\begin{array}{l}2.64 \\
3.13\end{array}$ & $\begin{array}{l}1.40 \\
1.10\end{array}$ \\
\hline $\begin{array}{r}99.37 \\
103.54\end{array}$ & $\begin{array}{l}\text { GLOBOCAS } \\
\text { GLOBOCAS }\end{array}$ & $\begin{array}{l}3.13 \\
3.22\end{array}$ & $\begin{array}{l}1.10 \\
1.12\end{array}$ \\
\hline 103.54 & PRENZI & 2.53 & 1.65 \\
\hline 109.11 & PWUELL & 2.25 & 1.30 \\
\hline 113.47 & GLOBOCAS & 3.36 & 1.04 \\
\hline 113.47 & PWUELL & 2.34 & 1.54 \\
\hline 117.25 & GLOBOCAS & 2.84 & 1.30 \\
\hline 117.25 & PWUELL & 2.23 & 1.64 \\
\hline 123.91 & $\mathrm{CIB}$ & 2.49 & 1.52 \\
\hline 124.11 & GLOBOCAS & 3.01 & 1.09 \\
\hline 124.11 & PRENZI & 2.44 & 1.49 \\
\hline 126.59 & PWUELL & 2.08 & 1.14 \\
\hline 128.51 & $\mathrm{ClB}$ & 2.14 & 1.06 \\
\hline 129.56 & CIB & 2.27 & 1.48 \\
\hline 132.71 & CIBKULL & 2.38 & 1.19 \\
\hline 132.71 & UVIGSTIL & 2.74 & $0.55^{*}$ \\
\hline 134.64 & CIB & 2.32 & 1.17 \\
\hline 137.20 & GLOBORID & 3.00 & $0.98^{*}$ \\
\hline 137.20 & PRENZI & 2.30 & 1.51 \\
\hline
\end{tabular}


Appendix B. (Continued).

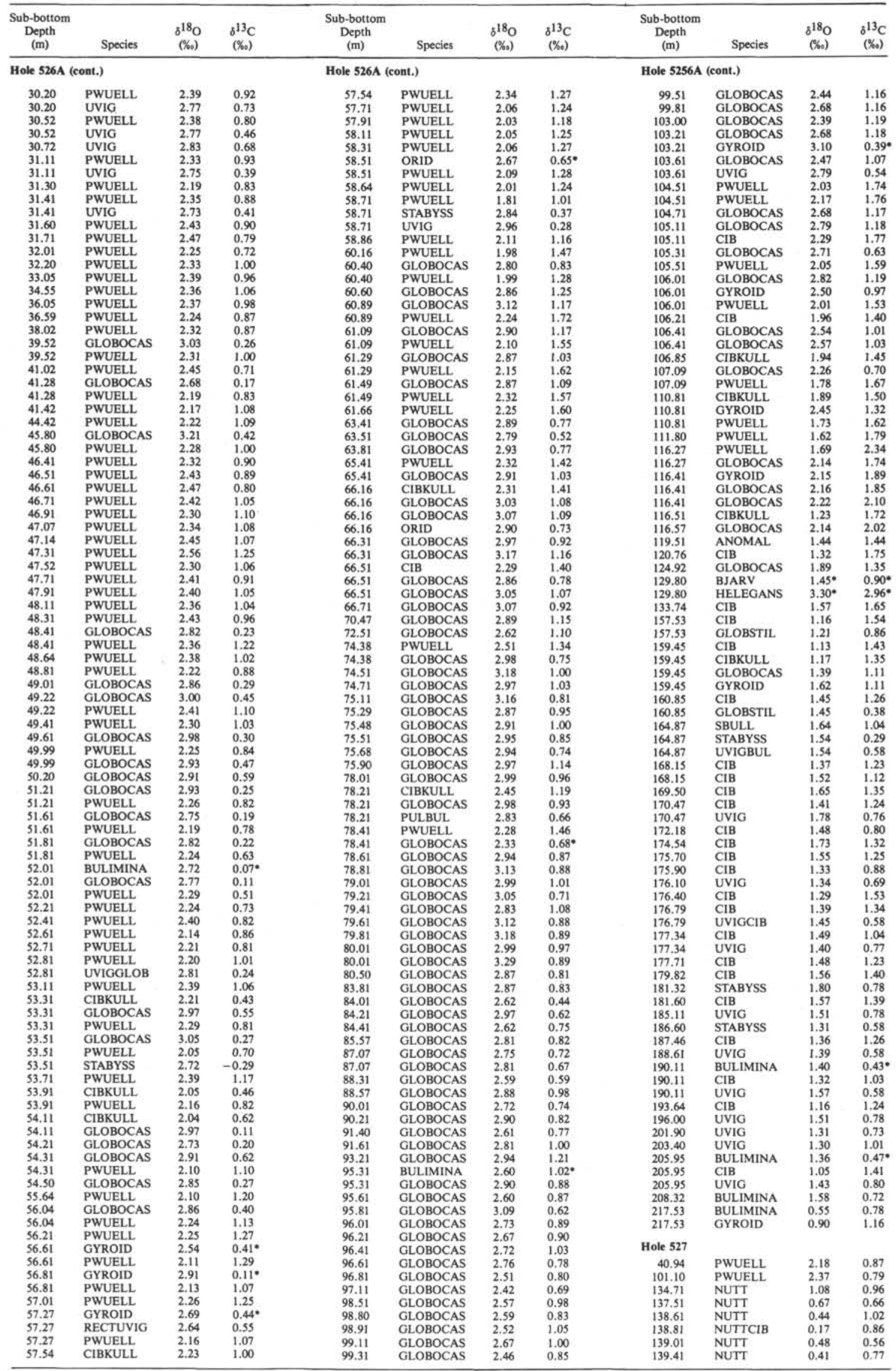


Appendix B. (Continued).

\begin{tabular}{|c|c|c|c|c|c|c|c|c|c|c|c|}
\hline $\begin{array}{l}\text { Sub-bottom } \\
\text { Depth } \\
\text { (m) }\end{array}$ & Species & $\begin{array}{l}{ }^{18} \mathrm{O} \\
(\%)\end{array}$ & $\begin{array}{l}{ }^{{ }^{13} \mathrm{C}} \\
(\%)\end{array}$ & $\begin{array}{l}\text { Sub-bottom } \\
\text { Depth } \\
\text { (m) }\end{array}$ & Species & $\begin{array}{l}\delta^{18} \mathrm{O} \\
(\%)\end{array}$ & $\begin{array}{l}{ }^{813} \mathrm{C} \\
\left.(\%)_{0}\right)\end{array}$ & $\begin{array}{l}\text { Sub-bottom } \\
\text { Depth } \\
\text { (m) }\end{array}$ & Species & 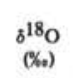 & $\begin{array}{l}{ }^{{ }^{13} \mathrm{C}} \\
\left(\%_{0}\right)\end{array}$ \\
\hline \multicolumn{4}{|c|}{ Hole 527 (cont.) } & \multicolumn{4}{|c|}{ Hole 528A (cont.) } & \multicolumn{4}{|c|}{ Hole 529 (cont.) } \\
\hline 143.29 & NUTT & 0.02 & 0.66 & 8.95 & UVIG & 3.52 & -0.05 & 131.49 & GLOBOCAS & 2.20 & 0.64 \\
\hline 143.11 & NUTTCIB & 0.33 & 0.60 & 9.05 & CIBKULL & 3.48 & 0.48 & 131.49 & GYROID & 2.50 & $0.65^{*}$ \\
\hline 142.88 & NUTT & 0.19 & 0.48 & 9.15 & GLOBOCAS & 4.27 & -0.52 & 135.71 & GLOBORID & 2.05 & 0.34 \\
\hline 142.71 & MIXED & 0.37 & 0.45 & 9.15 & UVIG & 3.94 & -0.26 & 141.46 & BULIMINA & 1.99 & 0.66 \\
\hline 142.71 & NUTT & 0.29 & 0.78 & 9.35 & ORID & 4.04 & -0.54 & 141.46 & GLOBOCAS & 2.29 & 0.76 \\
\hline 142.31 & NUTT & 0.17 & 0.57 & 9.35 & UVIG & 3.92 & -0.18 & 151.55 & BULIMINA & 2.05 & 0.47 \\
\hline 142.48 & NUTTCIB & 0.38 & 0.84 & 9.45 & GLOBOCAS & 3.99 & 0.03 & 156.21 & CIB & 1.79 & 1.24 \\
\hline 143.61 & NUTTCIB & 0.21 & 0.47 & 9.45 & UVIG & 3.90 & 0.13 & 160.75 & GLOBOCAS & 1.93 & 0.90 \\
\hline 143.75 & NUTTCIB & 0.46 & 0.76 & 9.55 & PWUELL & 3.05 & 0.66 & 160.75 & GYROID & 2.19 & 0.94 \\
\hline 143.98 & NUTTCIB & 0.19 & 0.55 & 9.55 & UVIG & 3.52 & 0.02 & 163.91 & BJARV & 2.35 & 1.47 \\
\hline 144.21 & NUTTCIB & 0.33 & 0.47 & 9.75 & GLOBOCAS & 3.65 & 0.13 & 168.89 & $\mathrm{CIB}$ & 1.75 & 1.33 \\
\hline 144.52 & NUTTCIB & 0.07 & 0.49 & 9.75 & UVIG & 4.03 & -0.50 & 168.89 & GLOBOCAS & 2.05 & 0.58 \\
\hline 144.79 & $\mathrm{ClB}$ & 0.09 & 0.69 & 9.95 & GLOBOCAS & 3.62 & 0.04 & 168.89 & GLOBOCAS & 2.10 & 0.88 \\
\hline 145.11 & NUTT & -0.10 & 0.24 & 9.95 & UVIG & 3.76 & 0.04 & 170.73 & CIB & 1.94 & 0.74 \\
\hline 145.31 & NUTT & -0.11 & 0.43 & 10.05 & CIBKULL & 3.53 & 0.70 & 170.73 & GYROID & 2.60 & 0.66 \\
\hline 145.76 & NUTTCIB & 0.07 & 0.38 & 10.05 & UVIG & 3.96 & -0.05 & 170.73 & STABYSS & 2.20 & $0.41^{\bullet}$ \\
\hline 146.28 & NUTTCIB & -0.15 & 0.33 & 10.15 & GLOBOCAS & 4.00 & -0.51 & 172.23 & $\mathrm{CIB}$ & 1.66 & 1.20 \\
\hline 146.77 & NUTTCIB & -0.03 & 0.89 & 10.15 & PWUELL & 3.23 & 0.20 & 175.23 & CIB & 1.62 & 1.20 \\
\hline 147.02 & NUTTCIB & -0.12 & 0.60 & 10.15 & UVIG & 3.88 & -0.37 & 175.41 & GLOBOCAS & 2.13 & 0.83 \\
\hline 147.68 & NUTTCIB & -0.21 & 1.02 & 10.25 & GLOBOCAS & 4.00 & -0.08 & 176.73 & CIBGLOB & 1.54 & 1.15 \\
\hline 147.93 & NUTT & -0.11 & 0.72 & 10.25 & UVIG & 4.05 & -0.02 & 178.23 & CIB & 1.44 & 0.01 \\
\hline 148.24 & NUTT & -0.41 & 0.64 & 10.35 & CIBKULL. & 3.24 & 0.96 & 179.62 & ORID & 1.87 & 0.13 \\
\hline 152.28 & NUTT & -0.19 & 0.97 & 10.35 & UVIG & 3.49 & 0.20 & 181.50 & $\mathrm{CIB}$ & 1.49 & 0.95 \\
\hline 164.69 & NUTT & -0.43 & 0.57 & 10.45 & CIBKULL. & 2.94 & 0.85 & 181.50 & ORID & 1.97 & $0.10^{\circ}$ \\
\hline 199.91 & NUTT & -0.21 & 0.77 & 10.55 & CIBKULL & 3.71 & 0.86 & 182.15 & CIB & 1.77 & 0.86 \\
\hline 199.51 & NUTT & -0.29 & 0.82 & 10.55 & PWUELL & 3.30 & 0.86 & 182.15 & BULSTIL & 1.96 & 0.51 \\
\hline 202.11 & CIB & 0.22 & 1.25 & 10.55 & UVIG & 3.89 & 0.05 & 183.41 & BJARV & 2.22 & 1.08 \\
\hline 202.11 & NUTTT & -0.10 & 0.95 & 10.62 & GLOBOCAS & 3.90 & 0.07 & 183.41 & GLOBOCAS & 2.34 & 0.88 \\
\hline 218.34 & ORID & 0.53 & 1.70 & 10.62 & ORID & 4.09 & -0.59 & 183.41 & ORID & 2.04 & $0.60^{\circ}$ \\
\hline 218.34 & $\mathrm{CIB}$ & 0.33 & 2.42 & 10.62 & PWUELL & 3.54 & 0.25 & 183.63 & $\mathrm{CIB}$ & 1.54 & 1.12 \\
\hline 218.34 & NUTT & 0.12 & 2.02 & 10.62 & UVIG & 3.86 & -0.02 & 183.63 & ORID & 1.74 & $0.35^{*}$ \\
\hline 218.34 & GAVELIN & 0.17 & 2.01 & 10.75 & CIBKULL & 3.35 & 0.97 & 184.87 & CIB & 1.52 & 1.22 \\
\hline 256.30 & ORID & 0.55 & 0.68 & 10.87 & CIBKULL & 2.99 & 0.93 & 184.87 & UVIGORID & 1.75 & 0.60 \\
\hline 258.10 & NUTTGAV & 0.20 & 1.02 & 10.87 & UVIG & 3.65 & -0.04 & 184.87 & GYROID & 2.07 & 0.98 \\
\hline 261.10 & NUTT & 0.19 & 1.37 & 10.95 & UVIG & 4.33 & 0.06 & 184.87 & GLOBORID & 1.80 & 0.65 \\
\hline 260.62 & GAVELIN & 0.15 & 1.02 & 11.03 & GLOBOCAS & 4.19 & -0.35 & 184.87 & STABYSS & 1.82 & 0.55 \\
\hline 267.31 & NUTT & 0.65 & 1.41 & 11.03 & UVIG & 3.89 & -0.32 & 185.13 & $\mathrm{CIB}$ & 1.84 & 0.98 \\
\hline 267.51 & ORID & 0.26 & 0.65 & 11.15 & UVIG & 4.14 & -0.37 & 185.13 & NOD & 1.94 & $0.65^{\circ}$ \\
\hline 267.72 & GAVELIN & -0.16 & 1.13 & 11.25 & GLOBOCAS & 3.83 & -0.06 & 185.57 & CIB & 1.55 & 1.27 \\
\hline 267.72 & NUTT & 0.50 & 1.29 & 11.35 & CIBKULL & 2.68 & 0.62 & 189.01 & MIXED & 2.05 & 0.70 \\
\hline 267.79 & NUTTGAV & -0.14 & 1.11 & 11.35 & UVIG & 3.46 & -0.35 & 192.98 & BJARV & 2.37 & 1.40 \\
\hline 267.79 & ORID & 0.32 & $0.65^{\circ}$ & 11.55 & CIB & 3.57 & 0.31 & 193.21 & BULIMINA & 2.44 & 1.00 \\
\hline 267.92 & GAVELIN & 0.58 & 1.12 & 11.64 & GLOBOCAS & 4.48 & -0.39 & 193.21 & GLOBORID & 2.34 & 0.73 \\
\hline 267.92 & NUTT & -0.02 & 1.32 & 11.64 & ORID & 4.10 & -0.78 & 194.18 & BJARV & 2.45 & 1.33 \\
\hline 267.92 & ORID & 0.42 & $0.57^{\circ}$ & 11.64 & PWUELL & 3.06 & 0.59 & 194.55 & BJARV & 2.55 & 1.64 \\
\hline 268.11 & GAVELIN & -0.02 & 1.19 & 11.64 & UVIG & 4.36 & -0.28 & 195.57 & BJARV & 2.44 & 1.59 \\
\hline 270.11 & ORID & 0.59 & $1.01^{\circ}$ & 11.75 & UVIG & 3.46 & -0.19 & 197.90 & GYROID & 1.95 & 1.01 \\
\hline 270.11 & NUTT & 0.42 & 1.28 & 11.85 & UVIG & 3.60 & -0.10 & 197.90 & UVIG & 1.82 & 0.66 \\
\hline 270.11 & NUTT & 0.58 & 1.36 & 24.25 & GLOBOCAS & 2.93 & 0.01 & 199.00 & BJARV & 2.38 & 1.58 \\
\hline 271.71 & NUTTGAV & 0.33 & 1.30 & 24.25 & GLOBOCAS & 3.01 & 0.39 & 199.00 & $\mathrm{CIB}$ & 2.22 & 1.81 \\
\hline 271.71 & ORID & 0.61 & $1.09^{\circ}$ & 44.35 & $\mathrm{ClB}$ & 2.61 & 0.49 & 199.20 & BJARV & 2.28 & 1.43 \\
\hline 271.92 & NUTT & 0.18 & 1.30 & 45.15 & CIB & 2.50 & 0.61 & 199.20 & ORID & 2.30 & 0.83 \\
\hline 271.92 & ORID & 0.56 & $0.94^{*}$ & 45.15 & UVIGGLOB & 3.05 & 0.29 & 199.50 & BJARV & 2.48 & 1.65 \\
\hline 273.25 & ORID & 0.32 & $1.06^{\circ}$ & & & & & 200.04 & BJARV & 1.32 & 0.77 \\
\hline 273.25 & NUTT & 0.35 & 1.31 & Hole 528 & & & & 200.04 & NUTT & 0.60 & 0.76 \\
\hline 276.21 & NUTTCIB & 0.15 & 1.39 & & & & & 200.04 & STABYSS & 1.06 & 0.80 \\
\hline 278.33 & NUTTCIB & 0.10 & 1.61 & 225.67 & NUTTCIB & 2.51 & 1.13 & 200.13 & BJARV & 1.47 & 0.95 \\
\hline 279.71 & NUTTGAV & 0.26 & 2.16 & 227.54 & NUTTCIB & 0.87 & 0.75 & 200.13 & NUTT & 0.91 & 0.88 \\
\hline 279.91 & NUTTGAV & 0.14 & 2.03 & 237.98 & CIB & 1.08 & 1.19 & 200.20 & BULIMINA & 1.73 & 0.87 \\
\hline 280.10 & NUTTGAV & 0.27 & 2.01 & 237.98 & NUTT & 0.92 & 0.69 & 200.78 & BJARV & 1.18 & 1.12 \\
\hline 280.28 & NUTT & 0.53 & 2.01 & 246.40 & NUTTCIB & 0.72 & 0.90 & 200.78 & NUTT & 0.58 & 1.14 \\
\hline 280.49 & NUTTGAV & 0.27 & 1.79 & 249.40 & NUTT & 0.31 & 0.17 & 201.39 & BJARV & 1.19 & 0.97 \\
\hline 280.68 & NUTT & 0.66 & 2.26 & 250.60 & NUTTCIB & 0.29 & 0.71 & 201.39 & NUTT & 0.47 & 0.77 \\
\hline 280.85 & NUTTGAV & 0.57 & 1.94 & 250.60 & ORIDBUL & 0.58 & $0.23^{\circ}$ & 201.53 & NOD & 1.30 & 0.84 \\
\hline 281.19 & NUTTGAV & 0.30 & 1.75 & 252.00 & NUTT & 0.33 & 0.81 & 202.58 & BJARV & 1.44 & 0.83 \\
\hline 281.40 & NUTT & 0.94 & 2.17 & 256.61 & NUTTCIB & -0.19 & 0.65 & 202.58 & NUTT & 0.89 & 0.76 \\
\hline 281.40 & NUTT & 0.94 & 2.17 & 257.47 & NUTTCIB & 0.07 & 1.01 & 205.20 & BJARV & 1.44 & 0.83 \\
\hline 281.59 & NUTT & -0.27 & $1.70^{*}$ & 263.01 & NUTTCIB & -0.52 & 1.03 & 206.60 & BULIMINA & 1.24 & 1.22 \\
\hline 281.59 & NUTT & 0.53 & 1.85 & 312.07 & NUTT & -0.14 & 0.65 & 207.35 & BJARV & 1.37 & 0.79 \\
\hline 281.59 & NUTT & -0.27 & 1.70 & 313.53 & NUTT & 0.05 & 1.32 & 207.35 & NUTT & 0.77 & 0.57 \\
\hline 281.59 & NUTT & 0.53 & 1.85 & 313.56 & NUTT & -0.02 & 1.36 & 207.35 & NUTT & 0.88 & 0.74 \\
\hline 282.00 & NUTTGAV & 0.20 & 2.03 & 313.82 & NUTT & -0.11 & 1.24 & 207.88 & ANOMAL & 0.34 & 0.67 \\
\hline 282.20 & NUTT & 0.22 & 1.70 & 314.21 & $\mathrm{CIB}$ & -0.12 & 1.08 & 207.88 & CIB & 0.47 & 0.73 \\
\hline & & & & 314.21 & NUTT & -0.18 & 1.32 & 207.88 & BULIMINA & 1.26 & 0.82 \\
\hline Hole 528A & & & & 315.99 & NUTT & 0.13 & 1.74 & 207.88 & ORID & 1.10 & 0.32 \\
\hline & & & & Hole 529 & & & & 207.88 & OSANGUL & 1.06 & 0.83 \\
\hline 8.87 & UVIG & 3.50 & -0.09 & nove 829 & & & & 222.50 & BJARV & 1.34 & 0.74 \\
\hline 8.95 & CIBKULL & 2.85 & 0.77 & 0.11 & HELEGANS & 3.61 & 2.89 & 222.50 & NUTT & 0.75 & 0.60 \\
\hline 8.95 & ORID & 3.49 & -0.41 & 0.11 & PWUELL & 2.19 & 1.01 & 268.84 & MIXED & -0.27 & 0.73 \\
\hline
\end{tabular}

Note: Asterisks denote values that have not been used in Appendix $\mathrm{C}$ or in the figures. In the majority of cases these are ${ }^{13} \mathrm{C}$ values for species whose departure from isotopic equilibrium is poorly defined or very variable; in a small number of cases it is suspected either that the sample was displaced or that the analysis was suspect. For explana-

tions of computer abbreviations, see Appendix A. 
APPENDIX C

Isotopic Analyses of Benthic Foraminifers from Sites 525-529, Adjusted on the Basis of Appendix A

\begin{tabular}{|c|c|c|c|}
\hline $\begin{array}{l}\text { Sub-bottom } \\
\text { Depth } \\
\text { (m) }\end{array}$ & $\begin{array}{c}\text { Age } \\
\text { (m.y.) }\end{array}$ & Species & $\begin{array}{l}\delta^{18} \mathrm{O} \\
(\%)\end{array}$ \\
\hline Hole 525B & & & \\
\hline 0.80 & 0.163 & UVIG & 3.95 \\
\hline 11.66 & 2.216 & MEAN & 3.60 \\
\hline 13.05 & 2.402 & MEAN & 3.30 \\
\hline 19.01 & 3.126 & PWUELL & 3.09 \\
\hline 19.34 & 3.138 & PWUELL & 3.25 \\
\hline 22.10 & 3.234 & MEAN & 3.25 \\
\hline 22.20 & 3.237 & MEAN & 3.32 \\
\hline 22.40 & 3.244 & MEAN & 3.52 \\
\hline 23.61 & 3.287 & GLOBOCAS & 3.18 \\
\hline 27.78 & 3.432 & GLOBOCAS & 3.19 \\
\hline 33.35 & 3.644 & GLOBOCAS & 3.01 \\
\hline 35.10 & 3.748 & GLOBOCAS & 3.20 \\
\hline 42.26 & 4.171 & PWUELL & 2.92 \\
\hline 44.88 & 4.326 & GLOBOCAS & 3.20 \\
\hline 48.05 & 4.513 & GLOBOCAS & 3.08 \\
\hline 54.08 & 4.841 & GLOBOCAS & 3.04 \\
\hline 55.58 & 4.923 & GLOBOCAS & 3.04 \\
\hline $\begin{array}{l}58.81 \\
59.11\end{array}$ & $\begin{array}{l}5.063 \\
5.074\end{array}$ & $\begin{array}{l}\text { GLOBOCAS } \\
\text { GLOBOCAS }\end{array}$ & $\begin{array}{l}2.99 \\
3.19\end{array}$ \\
\hline 60.31 & 5.116 & GLOBOCAS & 3.27 \\
\hline 61.71 & 5.164 & MEAN & 3.15 \\
\hline 62.01 & 5.175 & GLOBOCAS & 3.34 \\
\hline 62.91 & 5.206 & MEAN & 3.05 \\
\hline 63.21 & 5.217 & GLOBOCAS & 3.13 \\
\hline 66.81 & 5.342 & MEAN & 3.28 \\
\hline 66.91 & 5.346 & GLOBOCAS & 3.14 \\
\hline 67.41 & 5.363 & GLOBOCAS & 3.19 \\
\hline 67.91 & 5.381 & MEAN & 3.28 \\
\hline 70.61 & 5.475 & MEAN & 3.31 \\
\hline 70.68 & 5.478 & PWUELL & 3.34 \\
\hline 72.11 & 5.528 & MEAN & 3.11 \\
\hline 72.18 & 5.530 & PWUELL & 3.15 \\
\hline 73.61 & 5.580 & PWUELL & 3.31 \\
\hline 75.14 & 5.633 & GLOBOCAS & 3.20 \\
\hline 75.81 & 5.657 & MEAN & 3.37 \\
\hline 79.06 & 5.770 & MEAN & 3.17 \\
\hline 79.71 & 5.793 & MEAN & 3.17 \\
\hline 81.01 & 5.838 & PRENZI & 3.37 \\
\hline 82.06 & 5.875 & GLOBOCAS & 2.98 \\
\hline 82.31 & 5.884 & MEAN & 2.72 \\
\hline 82.49 & 5.890 & MEAN & 2.70 \\
\hline 82.93 & 5.905 & MEAN & 3.07 \\
\hline 88.01 & 6.083 & PRENZI & 3.15 \\
\hline 94.31 & 6.303 & MEAN & 2.93 \\
\hline 95.04 & 6.328 & MEAN & 2.92 \\
\hline 95.69 & 6.351 & GLOBOCAS & 2.75 \\
\hline 96.21 & 6.369 & GLOBOCAS & 3.12 \\
\hline 97.71 & 6.600 & GLOBOCAS & 2.97 \\
\hline 99.37 & 7.145 & MEAN & 3.00 \\
\hline 103.54 & 8.505 & MEAN & 3.13 \\
\hline 109.11 & 9.228 & PWUELL & 2.89 \\
\hline 113.47 & 9.794 & MEAN & 3.12 \\
\hline 117.25 & 10.285 & MEAN & 2.81 \\
\hline 123.91 & 10.932 & CIB & 2.99 \\
\hline 124.11 & 10.948 & MEAN & 2.98 \\
\hline 126.59 & 11.142 & PWUELL & 2.72 \\
\hline 128.51 & 11.293 & CIB & 2.64 \\
\hline 129.56 & 11.375 & CIB & 2.77 \\
\hline 132.71 & 11.623 & MEAN & 2.81 \\
\hline 134.64 & 11.774 & CIB & 2.82 \\
\hline 137.20 & 11.975 & MEAN & 2.95 \\
\hline 139.18 & 12.645 & MEAN & 3.07 \\
\hline 139.41 & 12.734 & MEAN & 2.75 \\
\hline 139.46 & 12.753 & GLOBOCAS & 2.68 \\
\hline 139.61 & 12.801 & MEAN & 2.75 \\
\hline 139.81 & 12.811 & MEAN & 2.87 \\
\hline 140.01 & 12.820 & PWUELL & 2.86 \\
\hline 140.21 & 12.830 & MEAN & 2.56 \\
\hline 140.41 & 12.839 & MEAN & 2.87 \\
\hline 140.71 & 12.853 & PWUELL. & 3.14 \\
\hline 140.91 & 12.863 & UVIGGLOB & 2.86 \\
\hline 141.11 & 12.872 & PWUELL & 2.80 \\
\hline 141.31 & 12.881 & PWUELL & 3.01 \\
\hline 141.51 & 12.891 & PWUELL & 2.90 \\
\hline 141.71 & 12.900 & $\mathrm{CIB}$ & 2.80 \\
\hline 142.21 & 12.924 & PWUELL & 2.88 \\
\hline 142.41 & 12.933 & MEAN & 2.85 \\
\hline 142.61 & 12.942 & MEAN & 2.68 \\
\hline 142.81 & 12.952 & PWUELL & 3.03 \\
\hline 143.01 & 12.961 & PWUELL & 2.98 \\
\hline 143.41 & 12.980 & CIB & 2.59 \\
\hline 149.57 & 13.270 & PWUELL & 2.92 \\
\hline 153.47 & 13.453 & PWUELLL & 2.69 \\
\hline 155.65 & 13.555 & MEAN & 2.93 \\
\hline 157.91 & 13.753 & PWUELL & 2.90 \\
\hline 159.41 & 13.928 & PWUELL & 2.64 \\
\hline 162.31 & 14.266 & GLOBOCAS & 2.77 \\
\hline 163.81 & 14.441 & GLOBOCAS & 2.85 \\
\hline 166.45 & 14.750 & GLOBOCAS & 2.80 \\
\hline 166.61 & 14.768 & MEAN & 2.82 \\
\hline 169.90 & 15.152 & GLOBOCAS & 2.27 \\
\hline 174.60 & 15.627 & GLOBOCAS & 2.35 \\
\hline 174.61 & 15.628 & GLOBOCAS & 2.54 \\
\hline 174.71 & 15.635 & GLOBOCAS & 2.57 \\
\hline
\end{tabular}


Appendix C. (Continued).

\begin{tabular}{|c|}
\hline $\begin{array}{l}\text { Sub-bottom } \\
\text { Depth } \\
\text { (m) }\end{array}$ \\
\hline Hole 526A (c \\
\hline 60.16 \\
\hline 60.40 \\
\hline 60.60 \\
\hline 60.89 \\
\hline 61.09 \\
\hline 61.29 \\
\hline 61.49 \\
\hline 61.66 \\
\hline 63.41 \\
\hline 63.51 \\
\hline 63.81 \\
\hline 65.41 \\
\hline 66.16 \\
\hline 66.31 \\
\hline 66.51 \\
\hline 66.71 \\
\hline 70.47 \\
\hline 72.51 \\
\hline 74.38 \\
\hline 74.51 \\
\hline 74.71 \\
\hline 75.11 \\
\hline 75.29 \\
\hline 75.48 \\
\hline 75.51 \\
\hline 75.68 \\
\hline 75.90 \\
\hline 78.01 \\
\hline 78.21 \\
\hline 78.41 \\
\hline 78.61 \\
\hline 78.81 \\
\hline 79.01 \\
\hline 79.21 \\
\hline 79.41 \\
\hline 79.61 \\
\hline 79.81 \\
\hline 80.01 \\
\hline 80.50 \\
\hline 83.81 \\
\hline 84.01 \\
\hline 84.21 \\
\hline 84.41 \\
\hline 85.57 \\
\hline 87.07 \\
\hline 88.31 \\
\hline 88.57 \\
\hline 90.01 \\
\hline 90.21 \\
\hline 91.40 \\
\hline 93.21 \\
\hline 95.31 \\
\hline 95.61 \\
\hline 95.81 \\
\hline 96.01 \\
\hline 96.21 \\
\hline 96.41 \\
\hline 96.61 \\
\hline 96.81 \\
\hline 97.11 \\
\hline 98.51 \\
\hline 98.80 \\
\hline 98.91 \\
\hline 99.11 \\
\hline 99.31 \\
\hline 99.81 \\
\hline 99.51 \\
\hline 103.00 \\
\hline 103.21 \\
\hline 103.61 \\
\hline 104.51 \\
\hline 104.71 \\
\hline 105.11 \\
\hline 105.51 \\
\hline 106.01 \\
\hline 106.21 \\
\hline 106.41 \\
\hline 106.85 \\
\hline 107.09 \\
\hline 110.81 \\
\hline 111.80 \\
\hline 116.27 \\
\hline 116.41 \\
\hline 116.51 \\
\hline 116.52 \\
\hline 119.51 \\
\hline 120.76 \\
\hline 124.92 \\
\hline 133.74 \\
\hline 157.53 \\
\hline 159.45 \\
\hline 160.85 \\
\hline 164.87 \\
\hline 166.25 \\
\hline 167.75 \\
\hline \\
\hline
\end{tabular}

Note: If more than one analysis was made, a mean was taken. Ages are estimated as described in Shackleton et al. (this volume). 
APPENDIX D

Isotopic Analyses of Planktonic Foraminifers from Sites 525-529

\begin{tabular}{|c|c|c|c|c|}
\hline $\begin{array}{l}\text { Sub-bottom } \\
\text { Depth } \\
\text { (m) }\end{array}$ & $\underset{(\mathrm{m} . \mathrm{y.})}{\mathbf{A g e}^{\mathrm{ge}}}$ & Species & $\begin{array}{l}{ }^{18}{ }^{18} \mathrm{O} \\
\left(\psi_{0}\right)\end{array}$ & $\begin{array}{l}{ }_{8}^{13} \mathrm{C} C \\
\left(\mathrm{X}_{0}\right)\end{array}$ \\
\hline Hole 525B & & & & \\
\hline 99.37 & 7.145 & Globigerina bulloides & 3.10 & 0.94 \\
\hline 117.25 & 10.285 & Globigerinoides saccultifer & 0.53 & 2.66 \\
\hline 117.25 & 10.285 & Globigerina nepenthes & 0.47 & 2.26 \\
\hline 117.25 & 10.285 & Globorotalia conoidea & 1.07 & 2.08 \\
\hline 139.18 & 12.645 & Globoquadrina dehiscens & 1.07 & 1.90 \\
\hline 139.18 & 12.645 & Globogerina nepenthes & 0.87 & 2.48 \\
\hline 139.41 & 12.734 & & 0.83 & 2.48 \\
\hline 139.41 & 12.734 & & 0.85 & 1.81 \\
\hline 139.61 & $\begin{array}{l}12.801 \\
12.801\end{array}$ & $\begin{array}{l}\text { G. dehiscens } \\
\text { Globigerina nepenthes }\end{array}$ & 0.94 & 1.84 \\
\hline $\begin{array}{l}139.61 \\
139.81\end{array}$ & $\begin{array}{l}12.801 \\
12.811\end{array}$ & $\begin{array}{l}\text { Globigerina nepenthes } \\
\text { G. nepenthes }\end{array}$ & $\begin{array}{l}0.51 \\
0.72\end{array}$ & $\begin{array}{l}2.47 \\
2.54\end{array}$ \\
\hline $\begin{array}{l}139.81 \\
139.81\end{array}$ & $\begin{array}{l}12.811 \\
12.811\end{array}$ & & $\begin{array}{l}0.72 \\
0.74\end{array}$ & $\begin{array}{l}2.54 \\
1.83\end{array}$ \\
\hline $\begin{array}{l}139.81 \\
140.01\end{array}$ & 12.820 & Globigerina nepenthes & 0.75 & 2.59 \\
\hline 140.01 & 12.820 & Globoquadrine dehiscens & 0.91 & 1.84 \\
\hline 140.21 & 12.830 & Globigerina nepenthes & 0.47 & 2.55 \\
\hline 140.21 & 12.830 & Globoquadrina dehiscens & 0.50 & 1.90 \\
\hline 141.71 & 12.900 & G. dehiscens & 0.71 & 2.19 \\
\hline 141.71 & 12.900 & G. dehiscens & 0.78 & 1.65 \\
\hline 174.61 & 15.628 & Globigerinoides sacculifer & 1.00 & 3.55 \\
\hline 174.71 & 15.635 & Globoquadrine dehiscens & 1.38 & 3.02 \\
\hline 174.91 & 15.650 & Globigerinoides sacculifer & 0.94 & 3.44 \\
\hline 175.31 & 15.680 & G. sacculifer & 1.05 & 3.52 \\
\hline 175.51 & 15.695 & Globoquadrina dehiscens & 1.16 & 2.65 \\
\hline 175.51 & 15.695 & Glabigerinoides sacculffer & 1.10 & 3.43 \\
\hline 175.81 & 15.717 & G. socculiffer & 0.75 & 2.98 \\
\hline 176.01 & 15.732 & G. sacculter & 0.68 & 3.08 \\
\hline 176.21 & 15.746 & G. sacculiffer & 0.63 & 3.32 \\
\hline 176.41 & 15.761 & G. sacculiffer & 0.48 & 3.08 \\
\hline 176.41 & 15.761 & Globoquadring altispira & 0.77 & 2.48 \\
\hline 188.71 & 16.671 & Globigerinoides sacculffer & 0.30 & 3.06 \\
\hline 189.51 & 16.731 & Globigerinoides spp. & 0.85 & 3.00 \\
\hline 191.41 & 16.871 & G. spp. & 0.76 & 3.64 \\
\hline 191.61 & 16.886 & G. spp. & 0.71 & 3.38 \\
\hline 194.21 & 17.165 & G. spp. & 0.52 & 3.14 \\
\hline & & & & \\
\hline Hole 525A & & & & \\
\hline & 46.600 & Morozovellg spp. & & \\
\hline $\begin{array}{l}279.10 \\
279.63\end{array}$ & 46.600 & Morozovella spp. & -0.11 & 3.00 \\
\hline & 46.733 & M. aragonensis & -0.19 & 2.81 \\
\hline $\begin{array}{l}281.10 \\
282.60\end{array}$ & 47.101 & & -0.35 & 3.26 \\
\hline $\begin{array}{l}282.60 \\
284.10\end{array}$ & 47.477 & M. aragonensis & -0.45 & 3.54 \\
\hline $\begin{array}{l}284.10 \\
287.10\end{array}$ & 47.860 & M. aragonensis & -0.23 & 3.03 \\
\hline $\begin{array}{l}287.10 \\
288.60\end{array}$ & 48.710 & M. aragonensis & -0.07 & 3.12 \\
\hline $\begin{array}{l}288.60 \\
288.60\end{array}$ & 49.135 & M. subbotinae & 0.31 & 1.75 \\
\hline 288.60 & 49.135 & M. lensiformis & -0.13 & 2.72 \\
\hline 289.10 & 49.277 & M. aragomensis & 0.03 & 2.66 \\
\hline 290.51 & 49.677 & M. aragonensis & -0.19 & 3.04 \\
\hline 292.01 & 50.050 & M. spp. & -0.15 & 2.42 \\
\hline 293.51 & 50.256 & M. spp. & -0.39 & 2.34 \\
\hline 295.01 & 50.462 & M. spp. & -0.40 & 3.18 \\
\hline 298.01 & 50.875 & M. aragonensis & -0.51 & 2.97 \\
\hline 302.39 & 51.477 & M. spp. & -0.68 & 3.14 \\
\hline 322.79 & 53.502 & M. spp. & -0.96 & 3.34 \\
\hline 337.85 & $\$ 4.604$ & M. aragonensis & -1.21 & 2.53 \\
\hline 358.19 & 55.808 & $M$. acuta & -0.79 & 2.09 \\
\hline 358.19 & 55.808 & Subboting trilocularis & -0.65 & 1.24 \\
\hline 358.29 & 55.811 & Morozovella acuta & -1.02 & 2.28 \\
\hline 358.29 & 55.811 & Subbotina trilocularis & -0.82 & 1.10 \\
\hline 358.39 & 55.814 & Morozovella acuta & -0.98 & 2.24 \\
\hline 358.49 & 55.818 & M. acuta & -1.13 & 2.16 \\
\hline 358.49 & 55.818 & Subbotine trilocularis & -0.69 & 1.08 \\
\hline 358.59 & 55.821 & Morozovella acuta & -1.22 & 2.13 \\
\hline 358.59 & 55.821 & Subbotina trilocularis & -0.53 & 0.94 \\
\hline 358.69 & 55.824 & Chiloguembelina wilcoxensis & -0.80 & 0.24 \\
\hline 358.69 & 55.824 & Morozovella acuia & $\begin{array}{l}-0.60 \\
-1.10\end{array}$ & 1.96 \\
\hline $\begin{array}{l}358.69 \\
358.69\end{array}$ & 55.824 & Subbotina trilocularis & $\begin{array}{l}-1.10 \\
-0.63\end{array}$ & 0.70 \\
\hline 358.89 & 55.831 & Morozovella acuta & $\begin{array}{l}-0.03 \\
-0.42\end{array}$ & 2.13 \\
\hline 358.89 & 55.831 & Chiloguembelina wilcaxensis & -0.54 & 1.00 \\
\hline 358.89 & 55.831 & Morozovella subbotinae & -1.13 & 2.28 \\
\hline 358.99 & 55.834 & Chilloguembelina wilcoxensis & -0.47 & 1.03 \\
\hline 358.99 & 55.834 & Morozovella subbotinae & -1.05 & 2.32 \\
\hline 358.99 & 55.834 & M. acuta & -0.45 & 2.07 \\
\hline 358.99 & 55.834 & M. acuta & -0.66 & 2.01 \\
\hline 359.09 & 55.838 & Chiloguembeling wikcoxensis & -0.36 & 0.91 \\
\hline 359.09 & 55.838 & Morozovella subbotinae & -0.60 & 2.25 \\
\hline 359.19 & $\$ 5.841$ & M. subbotinae & $\begin{array}{l}-0.00 \\
-0.73\end{array}$ & 2.25 \\
\hline 359.19 & 55.841 & $\begin{array}{l}\text { M. Sullogurinate } \\
\text { Ching wilcoxensis }\end{array}$ & $\begin{array}{l}-0,03 \\
-0.40\end{array}$ & 0.79 \\
\hline 359.19 & 55.841 & Morozovella subbotinae & -0.82 & 2.13 \\
\hline 359.29 & 55.844 & Chiloguembelina wilcoxensis & -0.38 & 0.84 \\
\hline 359.39 & 55.848 & Morozovella subbotinae & -0.68 & 2.26 \\
\hline 359.39 & 55.848 & Chiloguembelina wilcoxensis & -0.26 & 0.93 \\
\hline 359.49 & 55.851 & a subbotinae & -0.85 & 2.11 \\
\hline 359.49 & 55.851 & Chiloguembelina wilcoxensis & -0.27 & 0.75 \\
\hline 359.59 & 55.854 & Morozovella subbotinae & -0.82 & 2.12 \\
\hline 359.59 & 55.854 & Chiloguembelina wilcoxensis & -0.48 & 0.82 \\
\hline 371.57 & 56.255 & Morozovella marginodentata & -1.16 & 2.29 \\
\hline 379.21 & 56.888 & M. subbotinae & -0.62 & 2,70 \\
\hline 379.21 & 56.888 & Subbotina patagonica & -0.28 & 1.74 \\
\hline 382.21 & $\$ 7.167$ & Morozovella marginodentata & -0.77 & 2.93 \\
\hline 382.21 & 57.167 & Subbotina patagonica & -0.39 & 1.78 \\
\hline 385.81 & 57,503 & adentata & -0.70 & 2.93 \\
\hline 385.81 & 57.503 & Subbotina patagonica & -0.43 & 1.68 \\
\hline 387.31 & 57.643 & Morozovella marginodentata & -0.67 & 2.90 \\
\hline
\end{tabular}


Appendix D. (Continued).

\begin{tabular}{|c|c|c|c|c|c|c|c|c|c|c|c|c|c|c|}
\hline $\begin{array}{l}\text { Sub-bottom } \\
\text { Depth } \\
\text { (m) }\end{array}$ & $\underset{(\mathrm{m}, \mathrm{y},)}{\mathrm{Age}}$ & Species & $\begin{array}{l}{ }^{818} \mathrm{O} \\
\left(\psi_{0}\right)\end{array}$ & $\begin{array}{l}{ }_{8}^{13} \mathrm{C} \\
{ }_{\left(\sigma_{0}\right)}\end{array}$ & $\begin{array}{l}\text { Sub-bottom } \\
\text { Depth } \\
\text { (m) }\end{array}$ & $\underset{(\mathrm{m} . \mathrm{y} .)}{\mathrm{Agc}}$ & Species & $\begin{array}{l}{ }^{18} \mathrm{O} \\
\left(\psi_{0}\right)\end{array}$ & $\begin{array}{l}{ }^{{ }^{13} \mathrm{C}} \\
\left(\%_{0}\right)\end{array}$ & $\begin{array}{l}\text { Sub-bottom } \\
\text { Depth } \\
\text { (m) }\end{array}$ & $\begin{array}{c}\mathrm{A}_{g t} \\
(\mathrm{~m}, \mathrm{y} .)\end{array}$ & Species & $\begin{array}{l}{ }_{8}^{18} \mathrm{O} \\
{ }_{\left(\mathbf{S}_{0}\right)}\end{array}$ & $\begin{array}{l}{ }^{813} \mathrm{C} \\
{ }_{(\%, 0)}\end{array}$ \\
\hline Hole 528 & & & & & \multicolumn{5}{|c|}{ Hole 529 (coat.) } & \multicolumn{5}{|c|}{ Hole 529 (cont.) } \\
\hline 228.29 & 37.285 & Globigerinatheka spp. & 0.02 & 2.58 & 141.46 & 28.982 & Catapsydrax sp. & 1.69 & 1.64 & 201.53 & 37.712 & G. cerroozulensis & 0.27 & 1.80 \\
\hline 252.00 & 47.302 & Morozovella aragonensis & -0.33 & 3.30 & 151.33 & 31.611 & C. sp. & 1.64 & 1.51 & 201.53 & 37.712 & Catapsydrax sp. & 0.41 & 1.78 \\
\hline 256.61 & 48.632 & M. spp. & -0.44 & 3.20 & 151.33 & 31.611 & Turborotalia spp. & 1.38 & 1.71 & 202.58 & 38.202 & Globigerina cerroazulensis & 0.57 & 1.82 \\
\hline 312.07 & 56.869 & M. subbotinge & -0.86 & 2.52 & 156.21 & 32.911 & Catapsydrax sp. & 1.33 & 1.86 & 202.58 & 38.202 & Catapsydrax sp. & 0.77 & 1.68 \\
\hline 312.07 & 56.869 & Subbotina patagonica & -0.45 & 1.56 & 156.21 & 32.911 & Globorotalia siakensis & 1.34 & 1.86 & 205.20 & 39.424 & Globigerinatheka index & 0.59 & 2.26 \\
\hline 312.99 & 57.464 & S. patagonica & -0.13 & 1.66 & 168.89 & 34.735 & Globigerina pseudoampliapertura & 1.35 & 1.96 & 205.20 & 39.424 & Globigerina cerroazulensis & 0.60 & 1.91 \\
\hline 312.99 & 57.464 & Morozovella rex & -0.68 & 2.72 & 168.89 & 34.735 & Catapsydrax sp. & 1.13 & 1.91 & 205.20 & 39.424 & Catapsydrax echinatus & 0.15 & 2.93 \\
\hline 313.36 & 57.623 & M. velascoensis & -1.06 & 3.65 & 175.41 & 34.873 & Globigerina psendoampliapertura & 1.25 & 1.86 & 205.20 & 39.424 & & 0.60 & 1.89 \\
\hline 313.56 & 57.623 & Subbotine patagonica & -0.26 & 2.21 & 175.41 & 34.873 & Turborotalia spp. & 1.41 & 1.80 & 205.20 & 39.424 & Turborotalia increbescens & 0.54 & 2.14 \\
\hline 313.82 & 57.640 & Morozovella acuta & -0.82 & 3.87 & 175.41 & 34.873 & Globigerina ewaperta & 1.34 & 2.12 & 205.20 & 39.424 & Globigerina winkleri & 0.64 & 2.04 \\
\hline 313.82 & 57.640 & Subbotina patagonica & -0.32 & 2.22 & 175.41 & 34.873 & Catapsydrax sp. & 1.26 & 1.80 & 207.35 & 40.428 & Globigerinatheka index & 0.60 & 2.06 \\
\hline 314.21 & 57.666 & Morozovella subbotinoe & -0.77 & 3.42 & 176.73 & 34.901 & C. sp. & 1.00 & 1.60 & 207.35 & 40.428 & Globigerina cerroazulensis & 0.54 & 1.85 \\
\hline 314.21 & 57.666 & Subbotina patagonica & -0.24 & 2.17 & 183.41 & 35.043 & Globigerina cerroazulensis & 1.41 & 1.90 & 207.35 & 40.428 & G. corpulenta & 0.65 & 1.86 \\
\hline 315.99 & 57.782 & S. patagonice & -0.38 & 2.92 & $\begin{array}{l}183.41 \\
183.41\end{array}$ & 35.043 & Catapsydrax sp. & 1.19 & 1.63 & 207.35 & 40.428 & Catapsydrax sp. & 0.71 & 1.57 \\
\hline 315.99 & 57.782 & Morozovella rex & -0.80 & 4.22 & 183.63 & 35.048 & C. unicavis & 1.30 & 1.7 & 207.35 & 40.428 & Globigerinatheka subconglobata & 0.40 & 2.05 \\
\hline & & & -0.80 & 4.22 & $\begin{array}{l}183.63 \\
193.21\end{array}$ & 36.037 & C. sp. & 1.15 & 1.92 & 207.35 & 40.428 & Globigerina winkleri & 0.57 & 2.01 \\
\hline Hole 529 & & & & & 198.95 & 36.790 & C. sp. & 1.33 & 2.08 & 220.59 & 46.605 & Acarinina sp. & 0.62 & 2.86 \\
\hline 0.11 & 0.029 & Globigerinoides ruber & 0.47 & 1.11 & 199.20 & 36.823 & Globigerina pseudoeocaena & 1.17 & 2.25 & 220.59 & 46.605 & Globigerina cerroczulensis & 0.57 & 1.96 \\
\hline 37.77 & 12.079 & Globigerina nepenthes & 0.74 & 2.04 & 199.20 & 36.823 & Catapsydrax sp. & 1.21 & 2.10 & 222.50 & 47.497 & Catapsydrax unicavis & 0.94 & 1.60 \\
\hline 121.81 & 24.348 & G. tripartita & 1.30 & 1.78 & 200.04 & 37.017 & Globigerine cerroazulensis & 0.28 & 1.68 & 222.50 & 47,497 & Globigerina cerroazulensis & 0.46 & 1.82 \\
\hline 121.81 & 24.348 & Globoquadrina praedehtsoens & 1.43 & 1.83 & 200.13 & 37.059 & G. cerroazulensis & 0.46 & 1.87 & 222.50 & 47.497 & Globigerinatheka mexicana & 0.40 & 2.37 \\
\hline 121.81 & 24.348 & Catapsydrax sp. & 1.40 & 1.41 & 200.13 & 37.059 & alia increbescens & 0.37 & 2.07 & 222.50 & 47.497 & Globigerina winkleri & 0.65 & 2.11 \\
\hline 121.81 & 24.348 & Globoquadrina spp. & 1.39 & 1.54 & 200 & 37,059 & Globigerinatheka inde & 0.52 & 2.75 & 222.50 & 47.497 & Globigerinatheka subconglobata & 0.46 & 2.29 \\
\hline 121.81 & 24.348 & Globigerina ouachitensis & 1.40 & 1.72 & 200 & 37.059 & Globigerine winkleri & 0.66 & 2.09 & 222.50 & 47.497 & Catapsydrax sp. & 0.90 & 1.50 \\
\hline 121.81 & 24.348 & G. sellii & 1.47 & $\begin{array}{l}1.12 \\
1.83\end{array}$ & 200.13 & 37.059 & Catapsydrax sp. & 0.52 & 1.84 & 238.11 & 52.201 & Globorotalia bullbrooki & -0.63 & 1.34 \\
\hline 121.81 & 24.348 & Globoquadrina transdehiscens & 1.49 & 1.83 & 200.78 & 37.362 & Hantkenine spp. & 0.30 & 2.22 & 238 & 52.201 & G. pseudotopilensis & -0.57 & 1.62 \\
\hline 131.49 & 26.571 & Globigerina angulisuturalls & 1.08 & 1.66 & 200.78 & 37.362 & Globigerinatheks index & 0.21 & 2.73 & 238.11 & 52.201 & Morozovella aragonensis & -0.83 & 2.23 \\
\hline 131.49 & 26.571 & Catapsydrax sp. & 1.48 & 1.46 & 200.78 & 37.362 & Catapsydrax sp. & 0.59 & 1.95 & 238.11 & 52.201 & Chlloguembelina wil. & -0.63 & 0.70 \\
\hline 136.31 & 27.678 & Globigerina tripartite & 1.44 & 1.77 & 200.78 & 37.362 & Globigerina cerroazulensis & 0.37 & 2.17 & 238.11 & 52.201 & Marozovella soldadoensis & -0.83 & 1.62 \\
\hline 136.31 & 27.678 & G. globularis & 1.23 & 1.46 & 201.39 & 37.647 & Catapsydrax sp. & 0.62 & 1.90 & 238.11 & 52.201 & M. subbotinae & -0.24 & 1.04 \\
\hline 136.31 & 27.678 & G. angulisuturalis & 103 & 1.64 & 201,39 & 37.647 & Globigerinatheka index & 0.37 & 2.47 & 245.68 & 54.545 & M. spp. & -1.06 & 2.40 \\
\hline 136.31 & 27.678 & Cotapsydrax unicaves & 1.16 & 1.38 & 201.39 & 37.647 & Catapsydrax unicavus & 0.72 & 1.70 & 268.84 & 57.639 & M. spp. & -0.80 & 2.81 \\
\hline $\begin{array}{l}130.31 \\
136.31\end{array}$ & 27.678 & Globigerina gortanit & 1.21 & 1.47 & 201.53 & 37.712 & Globigerina gortanii & 0.97 & 2.07 & & & & & \\
\hline
\end{tabular}

Note: Ages are estimated as described in Shackleton et al. (this volume). 